\title{
As transformações no modelo de desenvolvimento econômico chinês: de Deng Xiaoping ao período atual
}

\author{
Caroline Giusti de Araújo ${ }^{1}$ \\ Caroline Miranda Brandão² \\ Antônio Carlos Diegues 3
}

\begin{abstract}
Resumo: O trabalho tem como objetivo apresentar as transformações no modelo de desenvolvimento econômico chinês a partir de uma análise das mudanças estruturais do país. Dessa forma, procura-se relacionar o período histórico com as fases do processo de industrialização. Inicia-se com o entendimento das facetas econômicas que embasaram as transformações políticas do período Deng Xiaoping, ou seja, a relação entre as necessidades da economia local, em face às transformações industriais, e o processo de abertura econômica. Esse período também traz importantes considerações a respeito de como a atuação do Estado nas políticas macroeconômicas chinesa sustentou o processo de inserção internacional diferenciada do país articulando e consolidando o tecido industrial local. Por fim, procura-se captar as transformações no desenvolvimento econômico chinês a partir dos anos 2000 em que houve uma mudança no núcleo do modelo com inclusão da estratégia de inovação ao cerne do processo, estimulando o fortalecimento de elos mais nobres para a estrutura produtiva do país.

Palavras-chave: Desenvolvimento econômico, Transformações estruturais, China.
\end{abstract}

The Chinese economic development model transformations: from Deng Xiaoping to the current period

Abstract: This paper aims to present the changes in the Chinese economic development model from an analysis of structural changes in the country. Thus, it

\footnotetext{
${ }^{1}$ Mestranda em Desenvolvimento Econômico pelo Instituto de Economia. Instituição: Universidade Estadual de Campinas Endereço: Rua Cáceres, 385. Bairro: Jardim Salles - Catanduva-SP. E-mail: carolgiustiaraujo@gmail.com ${ }^{2}$ Doutoranda em Teoria Econômica pelo Instituto de Economia. Instituição: Universidade Estadual de Campinas. Endereço: Rua Presidente Vagas, 195. Bairro: Vila Pavan - Americana-SP. E-mail: carolembm@gmail.com ${ }^{3}$ Coordenador do Núcleo de Economia Industrial e da Tecnologia - NEIT-IE Professor do Instituto de Economia da Unicamp Endereço: R. Eduardo Murilo de Magalhães, 401 - Estiva Gerbi-SP, Brasil. E-mail: acdieguesjr@gmail.com
} 
seeks to relate the historical period with the phases of the industrialization process. It begins with the understanding of the economic aspects that supported the political changes Deng Xiaoping period, the relationship between the needs of the local economy, due to industrial change, and the economic liberalization process. This period also brings important considerations as how the role of the state in China's macroeconomic policies supported the process of differentiated international insertion of the country articulating and consolidating the local industrial structure. Finally, it tries to capture the changes in China's economic development from the zooos when there was a change in the model of development with the emphasis in the innovation strategy, encouraging the strengthening of the links to the production structure of the country.

Keywords: Economic development, Structural changes, China.

Classificação JEL: O14, 025, 053.

\section{Introdução}

A economia chinesa reestruturou sua inserção internacional por meio da condução das políticas econômicas por parte do Estado rearranjando ao longo dos anos sua estratégia de desenvolvimento. $\mathrm{O}$ país se tornou um grande receptor de investimentos externos, com elevada participação no comércio internacional e saldo positivo na balança comercial em tecnologias mais nobres, o que indica reorientação da estratégia produtiva, dando sinais ao mundo de uma inserção diferenciada.

Nessa perspectiva, Medeiros (2008) destaca que o objetivo básico da estratégia do país asiático é "elevar o status internacional da China como potência econômica e política capaz de influenciar o sistema internacional" (MEDEIROS, 2008, p.1). Além disso, Cintra e Pinto (2015) reiteram a articulação estatal das políticas macroeconômicas, industrial, comercial, de ciência \& tecnologia e de defesa em prol da grande estratégia nacional e da conquista de uma posição internacional autônoma.

Considerando o quadro econômico chinês, o artigo apresenta os grandes marcos das transformações no modelo de desenvolvimento. Dessa forma, o trabalho primeiramente caracteriza a importância do processo de industrialização e inovação para o desenvolvimento econômico. Na sequência, avalia-se o período de Deng Xiaoping no qual houve a construção de um sistema político-econômico ao molde chinês, ou seja, o sistema mercantil-socialista e, como esse arcabouço somado a inserção internacional diferenciada do período foram conduzidos para atender as necessidades do país. Esta análise tem o intuito de mostrar a interação 
entre criação das Zonas Econômicas Especiais e a entrada do Investimento Externo Direto com a estratégia industrializante em que o Estado buscou estimular, principalmente, a formação de reservas e atração de know-how.

Pela condução das transformações econômicas e sociais o Estado chinês conseguiu articular a abertura econômica com políticas macroeconômicas visando estimular o desenvolvimento industrial. Nessa perspectiva, mantiveram-se sob décadas o câmbio depreciado, taxações diferenciadas regionalmente e política monetária controlada, em que o crédito era fornecido conforme a escolha dos setores a serem beneficiados. Articulando fatores políticos, econômicos e comerciais - os quais se apresentaram como oportunidades estratégicas de desenvolvimento para a China, como sua entrada na OMC em 2001 - o país reorientou sua inserção internacional a partir de meados dos anos 2000 expandindo o tecido industrial local para produção de produtos mais nobres.

Por fim, exibe-se a mudança no núcleo do modelo de desenvolvimento a partir dos anos 2000 com a inclusão da estratégia de inovação no cerne do processo. Percebe-se que esse período foi crucial para o desenvolvimento de elos mais nobres no tecido industrial local já que concomitante ao processo de catching up o país fomentou a seleção de setores estratégicos para este processo, ou seja, buscou formar players no mercado mundial. Dentre estes, destacam-se, a Lenovo (computadores), a Huawei (equipamentos de telecomunicações), a Haier (eletrodomésticos e eletroeletrônicos) e a Chery Automobile (automóveis). O processo remete a uma reinserção do país asiático nas cadeias globais de valor.

Além desta breve introdução apresenta-se no tópico 2 a indústria como motor do desenvolvimento econômico e a importância da inovação para o mesmo; no tópico 3, os aspectos econômicos da era Deng Xiaoping; no tópico 4, o modelo de desenvolvimento chinês a partir de meados dos anos 2000 e, por fim, breves considerações finais e o referencial bibliográfico.

\section{A indústria como motor do desenvolvimento econômico}

Considerando o objetivo deste trabalho em apresentar o processo de transformação no modelo de desenvolvimento econômico chinês a partir da industrialização, faz-se necessário discutir os benefícios desta para o desenvolvimento de um país. Nesse aspecto, destaca-se a explicação de Cano (2012) que o desenvolvimento econômico é resultado de um processo de crescimento com elevação da produtividade, o que acelera a taxa de investimento diversificando a estrutura de produção e de emprego, ou seja, intensifica-se assim o processo de industrialização e urbanização.

É necessário que a indústria avance e seja diversificada para reduzir a dependência internacional inclusive em sua relação simbiótica com a agricultura, 
caso contrário esta ficaria dependente da importação de insumos modernos e de bens de capital. Sendo assim, a indústria deveria, portanto, aumentar sua produtividade e alterar sua estrutura contribuindo para a diversificação da pauta exportadora e melhora das contas externas. Cano (2012) ressalta que "Não há, na história, país algum que se desenvolveu, prescindindo de uma generalizada industrialização e de um forte e ativo papel do Estado Nacional" (CANO, 2012, p. 832).

Prebisch (1949), por sua vez, apresenta fatores que destacam a importância do processo de industrialização: (i) posição na divisão internacional do trabalho haja vista que o progresso técnico conquistado pelos países industrializados não se distribui equitativamente através do comércio internacional, ao contrário, leva a uma posição subordinada para aqueles que não se industrializarem. $\mathrm{O}$ autor destaca:

Ela (a industrialização, destaque nosso) não constitui um fim em si, mas é o único meio de que estes dispõem para ir captando uma parte do fruto do progresso técnico e elevando progressivamente o padrão de vida das massas (PREBISCH, 1949, p. 72).

(ii) necessidade de utilizar os frutos do comércio exterior como elemento propulsor do desenvolvimento econômico na medida em que aqueles podem aumentar a produtividade do trabalho mediante a formação de capital. $\mathrm{O}$ desenvolvimento da indústria e a mecanização agrícola, necessária ao processo, requer elevada importação que pode ser sustentada pela exportação de produtos agrícolas, no caso da América Latina, e de produtos industriais de baixo valor agregado, no caso asiático;

(iii) a industrialização leva a uma melhor organização da classe sindical, que permite maior resistência à variação salarial ao longo dos ciclos econômicos em relação a países primário-exportadores;

(iv) a elasticidade renda das importações de bens manufaturados é superior aos bens primários que permite aos países industrializados melhores condições para lidarem com as restrições do balanço de pagamento promovidas pelo crescimento econômico.

Além disso, a indústria é capaz de gerar maior encadeamento na economia estimulando direta, indireta e induzidamente atividades em outros setores que permite aumento da renda e do emprego superior aqueles gerados pela atividade primária. O setor de serviços, por sua vez, desenvolve-se de maneira rápida e articulada ao processo de industrialização. Dessa forma, Morceiro (2012) destaca não apenas o elevado efeito multiplicador da atividade industrial, mas também a dependência das atividades agrícolas e do setor de serviços em relação à indústria. Esta teria, portanto, grande capacidade de puxar outros setores da economia. 
Destacam-se também as leis de Kaldor em que a primeira afirma haver correlação positiva entre crescimento da indústria de transformação e o crescimento do PIB para além da relação prevista pelas contas nacionais à medida que o setor manufatureiro puxa o desempenho da economia; a segunda lei, conhecida como Kaldor-Verdoorn, relaciona produção e produtividade da manufatura por meio da redução de custos médios com o aumento da produção (economia de escala estática), especialização gerada pelo aumento do mercado (economias de escala dinâmicas), aprendizados (learning by doing, learning by using, learning by interacting) e incorporação de aprendizado nas máquinas e equipamentos; a terceira lei estabelece relação forte e positiva da velocidade da expansão da indústria de transformação e do aumento da produtividade fora desse setor; a quarta lei elucida que a expansão das exportações geraria um ciclo virtuoso de crescimento, pois permitiria aumento dos investimentos, da expansão da demanda agregada e da produtividade, tornando os produtos nacionais competitivos internacionalmente que levaria a uma expansão da capacidade produtiva (MORCEIRO, 2012, p. 15).

Além da importância da indústria, é necessário destacar o papel da inovação à medida que esta tem sido objeto central da perspectiva industrial chinesa a partir da década de 2000. Assim, ressalta-se que a literatura (neo)schumpeteriana atribui à inovação um papel de destaque visto que esta destrói permanentemente estruturas antigas e cria novas dinâmicas coordenadas pela esfera empresarial. Dessa forma, o fenômeno do desenvolvimento econômico, caracterizado por essa corrente, enfatiza a dinâmica e assume que o sistema tem uma natureza transformadora, isto é, representa uma "mudança espontânea e descontínua nos canais do fluxo, perturbação do equilíbrio, que altera e desloca para sempre o estado de equilíbrio previamente existente" (SCHUMPETER, 1985, p. 75).

O desenvolvimento, nessa perspectiva, ocorre por meio da introdução de um novo bem, de um novo método de produção, de uma abertura de um novo mercado, da conquista de uma nova fonte, da oferta de matéria-prima ou bens semimanufaturados e do estabelecimento de uma nova organização de qualquer indústria. Dessa forma, a inovação é entendida como o motor do capitalismo.

Dosi (1988) destaca, por sua vez, que as mudanças estruturais e de desempenho industrial são resultados de aprendizado inovativo por parte das empresas, com ressalva a importância da contribuição de universidades e agências governamentais, pela difusão do conhecimento inovativo de produtos e processos e da seleção entre firmas. Outro conceito importante para compreensão da inovação definido pelo autor é o de "apropriabilidade" que se refere à capacidade dos

\footnotetext{
${ }^{4}$ Segundo Dosi (1988), curvas de aprendizado, segredos, lead times e patentes, ainda que de forma complementar, são os mecanismos de apropriação das inovações de processo.
} 
conhecimentos tecnológicos e dos artefatos técnicos, do mercado e do ambiente legal em viabilizar e proteger a inovação como ativos geradores de renda. Nota-se que a capacidade de apropriabilidade somada às oportunidades (avanços exógenos e cumulatividade de conhecimento endógeno a firma) respondem pelo compromisso das firmas com a inovação.

Além disso, Dosi (1988) ressalta que o processo de busca tecnológica na perspectiva da firma é cumulativo de forma que o futuro tecnológico da empresa é delimitado pelo que ela conseguiu desenvolver no passado. Ressalta-se ainda que, em termos de paradigma tecnológico, há uma combinação de fatores exógenos da inovação e fatores endógenos ao processo de concorrência e acumulação tecnológica da firma. "Mais do que isso, cada paradigma envolve modos de busca, bases de conhecimento e combinações entre as formas de conhecimento tecnológico públicas e privadas, que são muito específicos" (DOSI, 1988, p.12).

Lundvall (2007), por fim, buscou definir o sistema de inovação incluindo elementos que interagem na modelagem do processo inovativo com elementos que ligam inovação à performance econômica. $\mathrm{O}$ recurso mais importante na economia dessa forma é o conhecimento e o processo mais importante, o aprendizado. Com isso, o autor procurou apresentar um método para estudar o sistema nacional de inovação que se move do micro para o macro e volta ao micro: 1) firmas são unidades importantes para o sistema de inovação e seu modo de organização expressa como a inovação afeta a performance econômica; 2) firmas inovam em sua interação com outras; 3) atividades inovativas das firmas são dependentes do sistema educacional, do mercado de trabalho, do mercado financeiro, dos direitos de propriedade intelectual, entre outros; 4) firmas pertencentes a diferentes setores diferem em como inovam e interagem com as demais. O core do sistema de inovação é, portanto, firmas em interação com outras firmas e com a infraestrutura de conhecimento.

Como destacado por Dosi (1988) e Lundvall (2007), as firmas apresentam um papel crucial no desenvolvimento de novas tecnologias, sendo o locus da inovação. Porém, principalmente no caso de economias de industrialização tardia, como o caso da economia chinesa, o Estado tem uma atribuição de importância ímpar na inovação e na indústria, e, portanto, no desenvolvimento econômico de uma nação.

Dessa maneira, Mazzucato (2015) argumenta que o papel do Estado não deve se restringir a incentivar maiores investimentos em P\&D, mas além disso, o Estado também tem de ter como incumbência a direção dos investimentos. Em outras palavras, os policymakers deveriam se ocupar de quais tipos de políticas industriais que levarão determinada nação (ao menos em alguns setores) à fronteira do conhecimento. Isso permite uma nova expansão, abertura e até remodelação de mercados, permitindo que o capital privado possa também, então, beneficiar-se de 
tais mercados, que no decorrer do processo já parecem menos arriscados ao investimento privado. O papel de direcionamento de investimentos se desenha de forma fulcral para o Estado, pois os setores que se encontram na fronteira do conhecimento demandam investimentos mais incertos e onerosos que o capital privado teme em investir no início do processo. Como bem destaca Karl Polanyi, a ideia de que os mercados se autorregulam sem a presença do Estado é uma grande falácia: "A estrada do livre mercado foi aberta e mantida aberta pelo aumento crescente e continuo de intervencionismo centralizado e controlado" (POLANYI, 2001 apud MAZZUCATO, 2011, p. 30, tradução nossa).

Sob essa premissa, Chang (2002) também salienta que os demais países atualmente desenvolvidos (PADs) se utilizaram de diversos mecanismos, com forte atuação de seus governos, em nome do desenvolvimento de sua indústria, ou seja, uma linha de ação totalmente díspar do atual discurso de livres mercados. Ele cita os casos do Reino Unido, Estados Unidos, Alemanha, Japão, e Coreia do Sul. Todos se utilizaram de tarifas, subsídios e outros meios de promoção de suas indústrias, em seus estágios iniciais de desenvolvimento. Até mesmo a Suécia, que apresenta uma industrialização mais tardia que os alguns países citados anteriormente, também empregou o uso de tarifas, subsídios, cartéis e o suporte estatal em P\&D para o desenvolvimento de indústrias consideradas chave, como têxteis, ferro e engenharia. Ele aponta que uma exceção seria o caso da Holanda, que manteve o livre comércio durante o século XVIII. Contudo, Holanda já se encontrava na fronteira do conhecimento tecnológico nesse período, além de ter implementado medidas protecionistas agressivas, durante o século anterior, em prol de sua indústria marítima e comercial.

No que diz respeito ao fomento da inovação, Mazzucato (2015) ainda destaca que as tecnologias, que atualmente são primordiais e geraram spillovers para a economia de um modo geral, não foram objeto de investimento privado, mas do esforço direcionado de investimento estatal. As tecnologias que compõem os smartphone (internet, GPS, touchscreen) foram financiadas por órgãos públicos. Além disso, desde as tecnologias ligadas à tecnologia de informação até as energias limpas, o governo não somente financiou tais projetos (mainframes, internet, energia solar e eólica) como também criou uma rede de atores estatais e privados. Dessa forma, incentivou e financiou empresas privadas em tais segmentos, o que os bancos privados não fariam a princípio, dado o maior risco no estágio inicial de tais tecnologias. Aliado a isso, o Estado também foi responsável por favorecer atividades consideradas de fronteira tecnológica. Essa liderança estratégica em direção à ação em setores considerados de ponta, pelo Estado, é o que a autora cunhou por "Estado empreendedor"; em outras palavras, aquele que atua de modo a modificar as estruturas vigentes, por meio do processo inovativo, na direção do desenvolvimento econômico de um país. 
Amsden (2004) apresenta sua perspectiva de Estado Desenvolvimentista, que se assemelha em alguns aspectos à visão de Mazzucato (2015), no que diz respeito à forte presença do Estado no processo de catching up. Segundo a autora, o papel do Estado se caracteriza por realizar quatro funções: "ação por meio de bancos de desenvolvimento; gerenciamento de conteúdo local por parte da indústria nacional; 'exclusão seletiva' (abrir alguns mercados para transações estrangeiras e manter outros fechados); formação de firmas nacionais" (AMSDEN, 2004, p.227). A autora avalia que os países que se utilizaram de tais aparatos tiveram como consequências o desenvolvimento da indústria básica, dotada de economias de escala, além do desenvolvimento de habilidades tecnológicas e também ativos intangíveis. Dessa maneira, a autora investiga algumas experiências nas quais o Estado empreendedor se fez presente, e os desdobramentos para a indústria e o desenvolvimento econômico.

Segundo Amsden (2004), o primeiro ponto importante é a presença de bancos de desenvolvimento públicos voltados ao fomento da indústria. Salienta-se que os bancos de desenvolvimento eram responsáveis pela maior parcela do investimento de longo prazo, tanto na indústria quanto na infraestrutura. Estes tinham como função a captação de recursos, domestica ou internacionalmente, e depois emprestar a taxas de juros mais baixas, no mercado interno. Por exemplo, no caso coreano, por causa da inflação e do câmbio valorizado, o custo real de fazer um empréstimo, com a garantia do Korea Development Bank, era negativo, durante todo o período de 1966 até 1980.

A escolha de quais empresas se beneficiariam de tal investimento não se baseava nas áreas nas quais o país já apresentava vantagem competitiva. Os setores prioritários eram mais dinâmicos, ligadas à substituição de importações e também a setores de fomento à exportação. No caso coreano, os setores prioritários no recebimento de empréstimos eram ligados à exportação e indústrias que tinham capacidade de melhorar a estrutura industrial e também do balanço de pagamentos, ou seja, incluía indústrias ligadas à substituição de importações (AMSDEN, 2004).

No caso de Taiwan, a indústria pesada foi o primordial, de 1961 a 1964, sendo encarada como elemento fulcral para o desenvolvimento de longo prazo. Ao mesmo tempo, produtos voltados às exportações como relógios e outros eletrônicos também foram promovidos. Em 1982, o governo de Taiwan priorizou outros tipos de setores, considerados estratégicos (máquinas, partes de automóveis, maquinas elétricas, e tecnologia de informação), baseado em seis critérios: grandes efeitos de linkage; potencial de mercado consumidor; alta intensidade tecnológica; alto valor agregado; baixa intensidade energética e baixa poluição (AMSDEN, 2004). 
No que diz respeito ao incentivo às exportações, a experiência asiática se mostrou mais bem-sucedida, na construção de zonas especiais voltadas à exportação. Este se espraiou rapidamente por China, Tailândia, Taiwan, Coreia do Sul, Malásia e Indonésia. A Coreia do Sul, que se caracterizou pelo elevado número de exportações concedia benefícios baseados em metas de exportação às empresas. Os próprios empréstimos dos bancos de desenvolvimento estavam atrelados à capacidade de as firmas exportarem, ou seja, as firmas mais propensas a exportar tinham maior chance de captação de recursos, bem como a juros gradativamente mais baixos (AMSDEN, 2004).

Aliado a isso, grande parte desses países também passou a exigir conteúdo local na produção industrial, por parte de empresas multinacionais. O grande objetivo da política era o da construção de empresas nacionais que fizessem parte da cadeia de produção de grandes firmas internacionais, possibilitando que elas adquirissem conhecimento e construíssem capacidades tecnológicas em seu segmento (AMSDEN, 2004).

Percebe-se pelas perspectivas de diferentes autores que o mercado não é organismo suficiente para o desenvolvimento de setores que estejam na fronteira tecnológica. Isto se aplica não somente a economias emergentes, de industrialização tardia, como também ao caso recente da revolução da tecnologia e internet, no caso americano. O Estado sempre se mostra presente, por meio de mecanismo de investimentos, incentivos, financiamentos, abrindo mercados e diminuindo os riscos posteriores para o investimento privado. Amsden (2004) ressalta que o papel do Estado desenvolvimentista como o responsável por atrair o investimento privado pelo provimento de subsídios, induzindo empresas às atividades mais inovadoras. O caso coreano da indústria automobilística ilustra de maneira elucidativa a importância do Estado no desenvolvimento da indústria:

\footnotetext{
É verdade que o sucesso da indústria automobilística coreana foi alcançado pela iniciativa privada. Porém, também é verdade que tal sucesso, dificilmente poderia ser atribuído somente à competição via mercado. Os automóveis coreanos se defrontaram como grande competição externa, nas exportações. Não foi a competição que estimulou a indústria. Isso não significa que a competição não importe. Mas, é importante ressaltar que foi proporcionado a essas empresas o ambiente para que pudessem ter responsabilidade e criatividade em sua capacidade máxima. (KIM, 1997, p.39-40, apud AMSDEN, 2004, p. 141).
}

Essas experiências de outros países mostram que não apenas a consolidação da indústria é necessária ao processo de desenvolvimento econômico, mas também o avanço para setores em que a inovação é um elemento chave. Isto se deve, conforme anteriormente explorado, a constatação (neo)schumpeteriana de que é a 
partir do processo inovativo que as forças disruptivas promovem o desenvolvimento econômico. Esse processo ainda apresenta um forte investimento estatal, em diversas experiências de desenvolvimento, como mostrado por Chang (2002). O Estado atua nas pesquisas de setores mais dinâmicos, com inovações radicais e disruptivas. Esse mesmo processo se dá na perspectiva do desenvolvimento chinês, cuja presença do Estado na adoção de políticas industriais se fez extremamente importante para o processo de catching up chinês.

\section{A era Deng Xiaoping}

Em 1978 Deng Xiaoping assumiu o comando do Partido Comunista da China e iniciou as Quatro Grandes Modernizações na agricultura, indústria, defesa e ciência E tecnologia. Além disso, o líder chinês reprivatizou os campos, promulgou o $7^{\text {o }}$ Plano Quinquenal (1981-1985) que visava maior produção de eletricidade, transporte e comunicação para fomentar as relações econômicas interiores e exteriores da China. Como lembra Leão (2010):

(...) as reformas das "Quatro Modernizações" exerciam uma função de superar uma etapa do desenvolvimento do país não alcançada pela Revolução Cultural: melhorar as condições materiais e econômicas das classes mais pobres, mediante a elevação das forças produtivas no campo e na indústria, bem como da abertura controlada da economia (LEÃO, 2010, p. 35).

De acordo com o Relatório do $7^{\mathbf{0}}$ Congresso Nacional do Partido Comunista da China (2007), a abertura econômica representa uma reforma coordenada pelo partido comunista para desenvolver as forças produtivas e modernizar o país, fazendo um sistema socialista à forma chinesa. O relatório reitera que os esforços do partido passaram a ser o desenvolvimento econômico e isto encadeou a percepção da necessidade de promover um processo gradual de abertura econômica, em que os resultados podem ser observados na prosperidade da China. O relatório (2007) ressalta:

O rápido desenvolvimento representa o mais notável sucesso do novo período. O Partido desenvolveu a estratégia das três etapas para a modernização, levando o povo a trabalhar arduamente para promover o rápido desenvolvimento sustentado da China a uma taxa raramente vista no mundo. A economia da China, em tempos à beira do colapso, cresceu de forma a alinhar como a quarta maior do mundo e com um volume de importações e exportações que é o terceiro maior. O povo chinês, em tempos inadequadamente alimentado e vestido, goza no geral de uma vida razoavelmente confortável. A população pobre das áreas rurais caiu de mais de 250 milhões para 
pouco mais de 20 milhões. Os sucessos no desenvolvimento político, cultural e social chamaram a atenção do mundo (Relatório do $7^{\circ}$ Congresso Nacional do Partido Comunista, 2007, grifos nossos).

$\mathrm{Na}$ interpretação do relatório (2007) o caminho da abertura econômica respeita os aspectos do socialismo científico, adicionando ao "modus operandi" características chinesas. No entanto, o aspecto central do processo de abertura respalda na lógica em que foi realizada já que o intuito de Deng era atrair elementos capitalistas coordenados pelo Estado para viabilizar a modernização da economia, ou seja, o objetivo não era tornar o país uma economia de mercado.

Deng, em termos de mudanças, dissolveu as comunas, propôs uma nova reforma para o campo e instalou novo sistema de contratos que permitiu as famílias venderem a sua produção excedente, que duplicou a produção rural entre 1980 e 1986. Esse processo promoveu aumento da riqueza rural e estímulo à expansão da indústria de bens de consumo, ou seja, foi o gatilho inicial para o desenvolvimento industrial que estaria por vir.

Destaca-se ainda a importância das reformas no campo para o processo de industrialização da China com o desenvolvimento das TVEs ${ }^{5}$, que são cooperativas de produção industrial no meio rural de propriedade coletiva. Essas empresas foram criadas ainda na era Mao para produção de insumos agrícolas, mas geravam poucos empregos. Com o aumento da renda no campo, em razão do novo sistema de contratos, o camponês passou a fazer parte do mercado consumidor e esse novo mercado acabou exigindo inovações na forma de atuação das TVEs. Como destaca Milaré (2011), "O dinamismo proporcionado pelas TVEs à economia chinesa foi um impulso decisivo para o avanço na industrialização pós-1978" (MILARÉ, 2011, p.53). Além disso, a presença dessas empresas no meio rural gerando emprego e renda amenizava o êxodo rural.

As SOEs (State Owned Enterprises), empresas estatais chinesas, também auxiliaram o processo de transformação industrial do período passando por reformas que culminaram na independência financeira destas em relação ao Estado e, com isso, a formação de grandes conglomerados. O objetivo dessas reformas era permitir que as empresas tivessem escala e capacidade de investimento para auxiliar na modernização industrial. A questão, no entanto, é que o Estado nunca perdeu o comando dessas empresas, controlando-as de forma indireta, que o proporcionava a guiar o rumo da política industrial. De forma geral, “(...) a atuação das SOEs tem como objetivo final não apenas o lucro, mas o crescimento, a modernização e o desenvolvimento econômico e social do país" (MILARÉ, 2011, p.59).

\footnotetext{
${ }^{5}$ Townships and Villages Enterprises.
} 
O contexto geopolítico de Guerra Fria proporcionou à China acesso ao mercado norte-americano, por meio do Comunicado de Xangai ${ }^{6}$, e ao crédito no mercado externo, ou seja, fez com que o país conquistasse capacidade de financiar as importações de máquinas e equipamentos sem alterar a estabilidade do seu balanço de pagamentos. De modo geral, a estratégia industrializante chinesa passava pelo ímpeto de fazer com que sua estrutura produtiva atendesse ao mercado externo, pois por meio das exportações o país conseguiria internalizar o dinamismo externo e assim, modernizar sua indústria.

Outras estratégias com mesmo intuito foram: atração de IDE, que além de trazer o capital externo produtivo, atraia know-how; o incentivo à cópia e à engenharia reversa; a manutenção do câmbio artificialmente desvalorizado; financiamento estatal para novos empreendimentos a taxas de juros menores; altas taxas de investimento, entre outras. Tratavam-se de estratégias elaboradas pelo Estado que viabilizavam a presença do mercado sem a perda da autonomia nacional. Essa atuação participativa do Estado chinês no comando do processo de industrialização e desenvolvimento econômico do país pode ser entendida pela ótica de que a convergência de renda entre os países industrializados e os não industrializados não se trata de um resultado natural da dinâmica econômica.

Salienta-se também a maneira que a abertura econômica chinesa se deu no contexto de globalização, que permitiu ao país se articular ao mercado internacional, obtendo insumos para suas indústrias exportadoras e abrindo novos mercados consumidores para os seus produtos. Para uma vertente de estudiosos do tema, a diferença de acoplamento da China ao processo de globalização se deu pela atuação do Estado, que se reaproximava diplomaticamente dos países capitalistas e direcionava o processo de abertura da economia privilegiando a integração produtiva, de forma que o investimento direto pôde ser direcionado para setores com cadeias mais dinâmicas.

Ressalta-se ainda que se regulava o timing de liberalização da conta capital, privilegiando o IDE em detrimento de investimentos de curto prazo, ou seja, faziase com que o processo atendesse as peculiaridades da economia local não se tornando refém das intempéries internacionais. Outro aspecto importante na condução do processo de abertura foi o fortalecimento do sistema bancário do setor público, tornando-o capaz de fornecer e controlar a concessão de crédito para a realização dos investimentos na área industrial. Com relação à estrutura do sistema financeiro, ao qual o sistema bancário está inserido, faz-se uma ressalva de que todo o sistema é controlado pelo Conselho Nacional do Povo e pelo Conselho de Estado, ou seja, pelo Partido Comunista da China. Como pode ser visto em Leão (2010):

${ }^{6} \mathrm{O}$ Comunicado de Xangai deu início à normalização das relações diplomáticas sino-americanas. 
(...) pode-se afirmar que a China impôs controles de capital a fim de impedir a entrada de investimentos especulativos e utilizou o IDE e, especialmente, o crédito dos bancos públicos para realizar os grandes projetos de infraestrutura e desenvolvimento da estrutura produtiva e fomentar as indústrias exportadoras de alta tecnologia. Assim, a expansão dos investimentos, da produção e das exportações respondeu a uma lógica interna de acumulação capitalista conduzida pelo Estado chinês, não se submetendo àquele alinhamento das posições que os países desenvolvidos foram impondo aos em desenvolvimento (LEÃO, 2010, p.42).

No sétimo Plano Quinquenal houve a criação das $Z_{E E s}{ }^{7}$ que visavam estimular a produtividade industrial e o desenvolvimento de toda a classe de serviços. Estas caracterizam-se por serem áreas selecionadas pelo governo chinês para a entrada do capital externo na forma de investimentos de longo prazo. Percebe-se que as regiões que fazem parte das ZEEs foram as maiores responsáveis pelo desenvolvimento industrial e financeiro da China em razão das benesses do regime chinês que promovia a abertura econômica com diretrizes desenvolvimentistas.

De acordo com Suleiman (2008), essas regiões tinham objetivo de estimular a modernização e o progresso principalmente nos setores industriais e exportadores. As principais zonas especiais criadas na época foram em regiões estratégicas, próximas ao litoral e a centros que já se desenvolviam de forma capitalista: Shenzen (próxima a Hong Kong), Zhulai (próxima a Macau), Shantou - todos da província de Guangdong, Xiamen (próximo a Taiwan) - da província de Fujian e uma área especial na ilha Hainan, pouco desenvolvida economicamente. Como lembra Milaré (2011):

Por se situarem próximas ao litoral, algumas ZEEs puderam se inserir na cadeia produtiva global como uma espécie de intermediário entre os Estados Unidos e os países mais desenvolvidos do Leste/Sudeste asiático, como Japão e Coréia do Sul. A China passou a importar partes, peças e componentes dos EUA e vender produtos finais montados -inicialmente de baixa intensidade tecnológica - para Japão, Coréia e Taiwan (MILARÉ, 2011, p. 67).

É possível ainda analisar pela Tabela 1 o rápido crescimento do PIB real nessas regiões ao longo dos anos.

\footnotetext{
${ }^{7}$ Zonas Econômicas Especiais.
} 
Tabela 1: Produto Interno Bruto real das ZEEs (em bilhões de yuan).

\begin{tabular}{c|c|c|c|c|c|c|c|c|c|c}
\hline Regiões & 1979 & 1980 & 1985 & 1990 & 1991 & 1992 & 1995 & 1996 & 1997 & $1979-1997$ \\
\hline Shenzhen & 0,2 & 0,3 & 2,3 & 6,2 & 6,9 & 8,7 & 13,6 & 15,1 & 17,4 & $8600 \%$ \\
\hline Zhuhai & 0,2 & 0,2 & 0,7 & 1,5 & 2,1 & 3,1 & 3,4 & 3,6 & 3,9 & $1850 \%$ \\
\hline Shantou & 0,9 & 0,9 & 1,7 & 2,6 & 3,2 & 3,6 & 5,2 & 5,9 & 6,9 & $667 \%$ \\
\hline Xiamen & 0,5 & 0,6 & 1,2 & 1,7 & 2,0 & 2,3 & 4,6 & 5,5 & 6,7 & $1240 \%$ \\
\hline Hainan & 1,7 & 1,8 & 3,1 & 4,0 & 4,6 & 6,3 & 7,5 & 7,9 & 8,4 & $394 \%$ \\
\hline Total ZEE & 3,4 & 3,8 & 9,0 & 14,8 & 18,8 & 24,0 & 34,3 & 38,0 & 43,3 & $1174 \%$ \\
\hline Total China & 392 & 417 & 703 & 694 & 1.014 & 1.137 & 1.61 & 1.786 & 1.963 & $401 \%$ \\
\hline
\end{tabular}

Fonte: Celino (2006) apud Knoth (2000) ${ }^{8}$.

Destaca-se que o Estado dispendeu parte de seu orçamento no desenvolvimento da infraestrutura das ZEEs por meio de subsídios fiscais e investimento em qualificação de mão-de-obra com vistas a atender as necessidades das empresas. No que diz respeito aos incentivos oferecidos pelo Estado, Celino (2006) destaca a redução/isenção do imposto de importação (inclusive para insumos), eliminação/redução de controles cambiais, menores restrições à propriedade estrangeira e a repatriação do lucro, menor pagamento de imposto de renda em relação ao resto do país, autonomia para contratar e demitir trabalhadores, entre outros.

A contrapartida pelas empresas era a transferência de tecnologia e a obrigatoriedade destas de demandarem matéria prima das empresas locais. A criação das ZEEs tinha uma perspectiva estratégica de absorção de tecnologia de outros países via atração das empresas multinacionais. Com isso, a forma de entrada dessas empresas na China se deu via modelo de joint venture no qual as empresas estrangeiras foram obrigadas a se associarem às empresas nacionais garantindo além da atração, a absorção do know how. Além disso, o processo fomentava as exportações e, com isso, garantia o acúmulo de reservas para o país.

Leão (2010) registra que o governo chinês ao ver o sucesso conquistado com a criação das ZEEs iniciais estimulou a formação de novas zonas especiais com objetivos mais específicos denominadas de Zonas de Desenvolvimento Econômico e Tecnológico (ZDET). Nessa perspectiva, o governo estabeleceu uma nova legislação tributária para beneficiar investimentos externos nessa região, principalmente em setores exportadores e intensivos em tecnologia. Tratava-se de incentivar formas mais proeminentes de atração de capital externo para produção de produtos de maior valor agregado. 
Dessa forma, percebe-se que a China dinamizou sua indústria e acelerou o processo de catching-up ao atrair empresas de países desenvolvidos e suas estruturas produtivas e técnicas de gestão. Reitera-se o contexto de internacionalização do capital na época da abertura das ZEEs, que fez com que a China representasse um porto atrativo para a reprodução de capital, dado seu baixo custo produtivo em relação ao resto do mundo. Ainda assim, a inserção chinesa nesse processo se deu sem a perda da soberania nacional.

Por fim, cabem ressaltar algumas mudanças no sistema econômico e financeiro que as ZEEs experimentaram e que foram difundidas por toda a China como a interligação entre as empresas estatais e o sistema de bolsa de valores, o estabelecimento do mercado de capitais no sistema financeiro, entre outras tantas enumeradas por Guanwen (2005) apud Celino (2006).

Com relação à entrada de IDE, a China foi uma grande receptora desse investimento já desde as décadas de 1980 e 1990, como pode ser visto no Gráfico 1, e o direcionamento desse tipo de investimento se deu vinculado as fases de abertura pelas quais a economia passava:

(...) Assim, durante o período inicial da reforma (1979-1986), os investimentos concentraram-se nas atividades de prospecção geológica, na indústria manufatureira trabalho-intensiva (indústria tradicional, especialmente têxtil e confecções de roupas) e no setor de serviços (atividades imobiliárias). A partir de 1986, com o início da segunda fase da abertura ao IDE, o governo chinês tomou uma série de medidas para mudar a estrutura setorial dos investimentos diretos recebidos, dirigindo-os para a indústria de transformação e para os setores export-oriented e de mais alta tecnologia (ACIOLY, 2005, p. 25).

Ainda segundo a autora, nos anos 1990 o país passou pela terceira e quarta fases de abertura e o IDE galgou maiores participações nas indústrias capitalintensivas - "A prioridade era o desenvolvimento e fortalecimento da indústria química, de máquinas e equipamentos de transporte, eletrônicos e comunicações" (ACIOLY, 2005, p.26). A autora destaca que atualmente o IDE tem se concentrado em atividades do setor de serviços, buscando o desenvolvimento de setores de tecnologia de ponta. 
Gráfico 1: Entrada de investimento direto externo em bilhões de dólares a preços correntes e participação, em percentual, da entrada de IDE na China em relação ao mundo (direita).

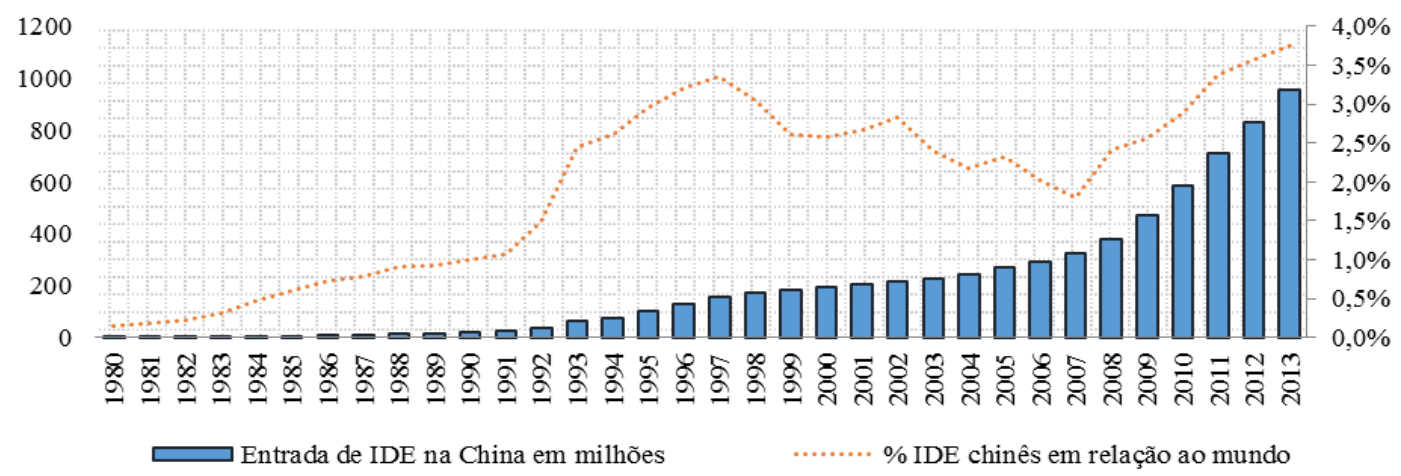

Fonte: Elaboração própria a partir de dados da UNCTAD.

Ainda com relação ao IDE, analisa-se que este foi direcionado para expansão da capacidade produtiva e das exportações. Dessa forma, a entrada desse investimento aconteceu para "estimular a concorrência, expandir a estrutura produtiva e disponibilizar recursos e tecnologias para setores típicos da terceira revolução industrial" (LEÃO, 2010, p. 41). O autor destaca ainda que havia a necessidade de saltar de um arcabouço tecnológico da primeira revolução industrial para a terceira, um processo que exigiu uma articulação firme entre capital externo e política industrial/tecnológica.

A entrada do capital externo na forma do IDE seguia a lógica de planejamento do Estado, que pode ser visto pelas estratégias preestabelecidas do governo para o uso desse capital. Cunha e Xavier (2010) avaliam, por exemplo, que 90\% do IDE que entrou na China foi destinado à modernização do capital e ampliação da capacidade produtiva existente. No que diz respeito à atuação do Estado, pode-se avaliar a diferenciação de tratamento das empresas estrangeiras em relação às nacionais em que estas mantinham baixos níveis de importação enquanto as empresas exportadoras podiam importar bens de capital e bens intermediários livres de impostos alfandegários. Percebe-se, portanto, que o governo estimulava as empresas estrangeiras a produzirem na China para exportar já que isso aumentaria as reservas do país e permitiria o aumento dos encadeamentos inter-setoriais além da absorção de técnicas modernas. Isto mostra que o país promoveu um ambiente macroeconômico e institucional diferenciado para o processo de abertura econômica que não se restringisse apenas a permitir a livre movimentação de capitais. 
No que se refere ao aparato macroeconômico sustentado pelo Estado para dar consistência à competitividade das empresas externas e nacionais que participavam do processo de industrialização, destaca-se a centralidade da taxa de câmbio. Segundo Milaré (2011), a desvalorização do câmbio tornou-se parte da política macroeconômica e industrial em 1984 e foi intensificada com o estabelecimento de um regime dual de câmbio - o oficial (administrado) e o mercado de swaps, que era restrito as empresas instaladas nas ZEEs e tradings Estatais.

A desvalorização do câmbio se deu principalmente durante o desenvolvimento do parque industrial do país para estimular a competitividade dos produtos produzidos na China. Além disso, funcionava como uma barreira comercial aos produtos importados - protegendo a indústria nascente. Pelo Gráfico 2 é possível ver que o processo de desvalorização cambial foi de 1980 a 1994 e de 1994 a 2005 o câmbio permaneceu desvalorizado em um patamar estável, um processo persuasivo na formação de expectativa dos agentes econômicos. Note que essa medida foi apontada pelos economistas estruturalistas, como Prebisch, como parte do processo de substituição de importações. Trata-se de uma maneira de equilibrar o balanço de pagamentos ao conter as importações e estimular as exportações.

Gráfico 2: Taxa de câmbio chinesa - yuan por dólar.

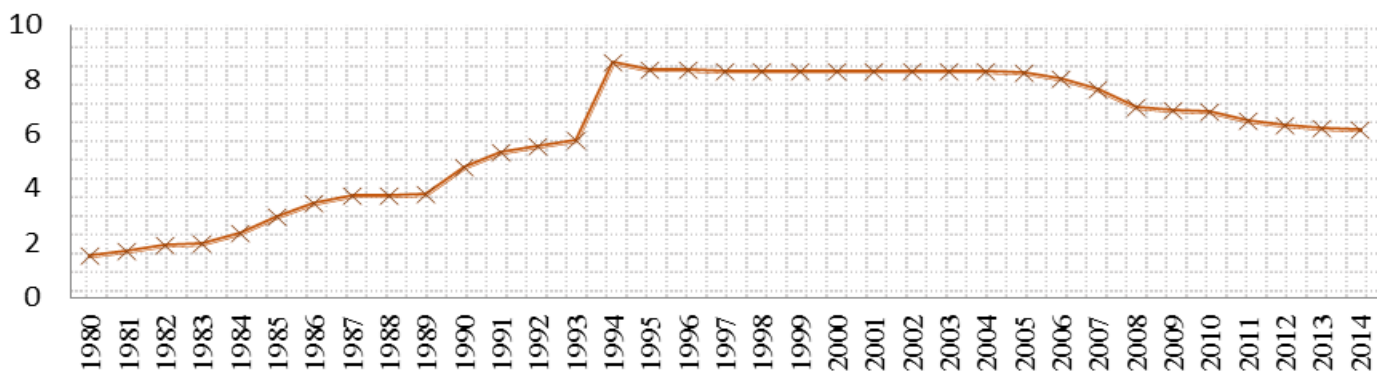

Fonte: Elaboração própria a partir de dados do Banco Mundial.

Destaca-se que o governo chinês manteve os níveis de preço da economia estáveis nos anos de 1999 a 2006, sem que a inflação ultrapassasse os $10 \%$ ao ano, como pode ser visto em Nonnemberg et al (2008). Outro aspecto macroeconômico relevante que o autor apresenta é com relação à dívida pública chinesa, percebe-se que a dívida é uma variável de difícil mensuração na China já que os bancos são públicos e que muitas das empresas devedoras também são públicas. Ainda assim, a posição patrimonial do governo em termos de dívida é negativa quando 
descontada a reserva nacional. Destaca-se ainda que o sistema financeiro é pouco desenvolvido, no entanto, é provável que a lógica desse sistema não seja a acumulação estritamente financeira, mas sim, o desenvolvimento da economia local e, por isso, a maior parte dos bancos ainda são públicos.

4. O modelo de desenvolvimento chinês a partir de meados dos anos 2000

A partir do ano de 2001 as relações no comércio multilateral foram profundamente modificadas com a entrada da China na $\mathrm{OMC}^{9}$. $\mathrm{O}$ país precisou fazer profundas reformas para se adequar as normas da organização e facilitar as negociações comerciais, como eliminar barreiras tarifárias e não tarifárias que protegiam seu mercado interno, eliminar as quotas de importação, modificar as relações de exportação, importação e alocação das empresas estrangeiras, entre outros (SULEIMAN, 2008).

Milaré (2011) aponta algumas reformas como: (1) fim do mercado de swaps e liberalização ao acesso a outras moedas; (2) a substituição das cotas de importações por teto de tarifas em que a tarifa de importação seria baixa para um pequeno volume de importação - essa medida representa uma forma de liberalizar o acesso aos produtos internacionais de forma atenuada e (3) comprometimento em criar restrições à cópia e proteger a propriedade intelectual ${ }^{10}$.

Em termos de resultados da entrada da China na OMC, percebe-se que o país conseguiu expandir as exportações e ampliou sua inserção internacional como pode ser visto no Gráfico 3 .

Gráfico 3: Corrente de comércio chinesa após a entrada da China na OMC em bilhões de dólares (eixo esquerdo) e participação das exportações chinesas nas exportações mundiais em percentual (eixo direito).

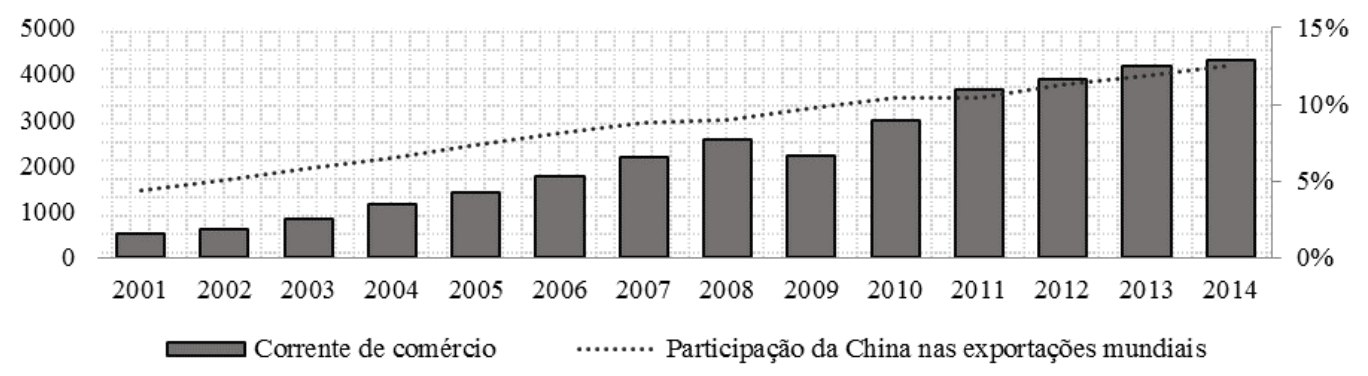

Fonte: Elaboração própria a partir de dados do TRADEMAP.

\footnotetext{
${ }^{9}$ Organização Mundial do Comércio.

${ }^{10} \mathrm{O}$ autor destaca que apesar dessa medida ter sido incluída na legislação chinesa, ela não é efetiva.
} 
Percebe-se pelo Gráfico 3 que a contrapartida da entrada da China na OMC e das flexibilizações das barreiras comerciais permitiram ao país um grande aumento do valor exportado e da corrente de comércio, que apresentaram queda apenas em 2008 com a crise financeira mundial. Entre 2001 e 2008 a média de crescimento da corrente de comércio chinesa foi de $18,73 \%$ apresentando menor crescimento nos anos de 2012, 2013 e 2014 (em torno de 7,3\%) que foi acompanhado pelas menores taxas de crescimento das exportações e nas importações, sendo que estas cresceram ainda menos que as exportações. A média de crescimento das exportações no período foi de $19,12 \%$ e das importações, $18,34 \%$.

O gráfico mostra também a participação das exportações chinesas nas exportações mundiais permitindo avaliar o impacto da entrada da China na OMC. Nota-se que em 2001 as exportações chinesas representavam 4\% das exportações mundiais e em 2014 o país representava 13\% com crescimento contínuo (ou estabilidade) ao longo dos anos. Milaré (2011) ao avaliar esse dado de 1978 a 2000 apresenta que a participação do país nas exportações mundiais não passou de 3\% no período.

O país exportou 266 bilhões de dólares em 2001 e 2.342 bilhões em 2014, ou seja, um grande salto em termos de valor exportado. Mas, além dessa análise é possível avaliar o tipo de produto exportado pelas indústrias chinesas após a entrada do país na OMC por tipo de tecnologia ${ }^{11}$. No Gráfico 4, apresenta-se que as exportações chinesas aumentaram principalmente em setores cuja tecnologia é diferenciada, intensiva em escala e trabalho. Esse processo mostra que a China não buscou apenas a inserção internacional como fábrica do mundo em produtos baratos, mas também construiu ao longo dos anos as bases para a transformação da sua estrutura produtiva.

Esse processo pode ser melhor evidenciado quando se analisa que em 2001 os produtos diferenciados e intensivos em trabalho não eram tão distantes em valor exportado mas, ao longo dos anos, apesar da exportação de produtos dos dois tipos de tecnologia terem crescido, os produtos diferenciados cresceram em proporção

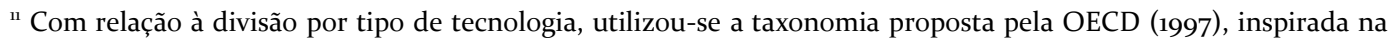
taxonomia clássica proposta por Pavitt (1984) em que se decompõe os setores industriais em intensivo em trabalho, escala, baseado em recursos naturais, ciência e diferenciado. De acordo com Nassif (2008) essa taxonomia relaciona os diferentes tipos de tecnologia ao principal fator responsável pela competitividade dos setores no curto e no longo prazo. Dessa forma, nos setores intensivos em recursos naturais, o principal fator competitivo é a abundância de recursos naturais; já nos setores intensivos em trabalho, o fator é a mão de obra barata (de baixa e média qualificação) quando comparado a outros países; nos setores intensivos em escala, dada a indivisibilidade tecnológica das plantas produtivas, o fator é a capacidade de produzir em grandes escalas; nos setores diferenciados, refere-se a capacidade de atender diversos padrões de demanda e por fim, no setor baseado em ciência, o fator é a aplicação de pesquisa científica às tecnologias industriais.
} 
maior e passaram a representar $46 \%$ das exportações chinesas em 2014 face a $36 \%$ em 2001, enquanto os produtos intensivos em trabalho retrocederam sua participação de $32 \%$ para $22 \%$ para o mesmo período.

Gráfico 4: Exportação da China por tipo de tecnologia (em bilhões dólares).

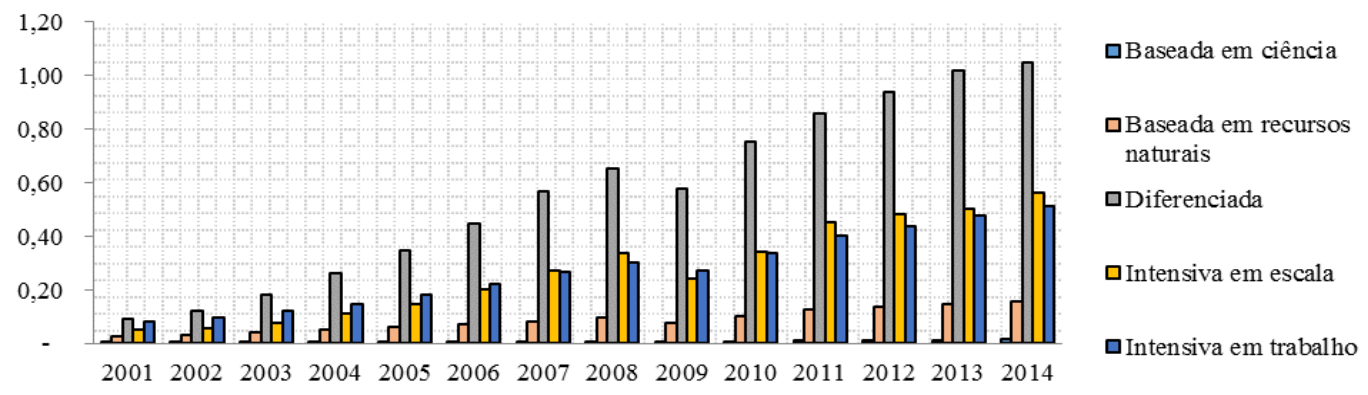

Fonte: Elaboração própria a partir de dados do TRADEMAP.

Nonnenberg (2014) ao estudar as cadeias globais de valor, relata que o objetivo dos países emergentes é superar suas vantagens relativas específicas e aumentar sua participação em atividades de maior valor agregado na cadeia produtiva, ou seja, deixar de ser apenas um montador final para ser um produtor de partes, peças e componentes. Dessa forma, com auxílio das informações contidas no Gráfico 4, infere-se que a China representa um caso de país que aumentou a intensidade tecnológica média de seus produtos nos últimos vinte anos. Entende-se que a exportação não é uma variável suficiente para avaliar esse movimento, mas o fato de apresentar uma evolução maior do volume de exportação de produtos com maior tecnologia agregada à cadeia produtiva pode representar o primeiro indicativo do processo de esforço inovativo do país.

Analisando os principais tipos de tecnologia em 2001, nota-se que as maiores atividades classificadas como intensivos em trabalho foram de algodão, lã, filamentos sintéticos e fibras sintéticas que representaram aproximadamente $63 \%$ do total exportado nessa tecnologia. Considerando os produtos diferenciados, observa-se que máquinas, reatores nucleares, caldeiras e equipamento elétrico e eletrônico representaram aproximadamente 90\% das exportações desse tipo de tecnologia. Por fim, analisa-se a tecnologia intensiva em escala em que os setores de químicos orgânicos, plásticos, artigos de plástico, ferro e aço representaram aproximadamente $52 \%$ do total exportado.

O setor exportador, dinâmico e em expansão, auxiliou o aumento das reservas chinesas, preponderantemente após 2001, como pode ser visto no Gráfico 5. Com isso, o país fomentava ainda mais o acesso ao dólar e, portanto, a 
capacidade de importar máquinas e equipamentos para auxiliar no processo de industrialização. As reservas também foram um importante aparato que permitiu ao governo manter o yuan desvalorizado durante o período de industrialização. $\mathrm{O}$ gráfico também permite avaliar que quando comparada à reserva da China em relação à reserva dos EUA, em dólar, percebe-se que o país apresentou quase oito vezes mais dólares que o país norte-americano como reserva em $2014^{12}$.

Gráfico 5: Total de reservas da China e dos EUA incluindo ouro, em dólares corrente, (eixo esquerdo) e participação percentual da reserva chinesa na norte-americana (eixo direito).

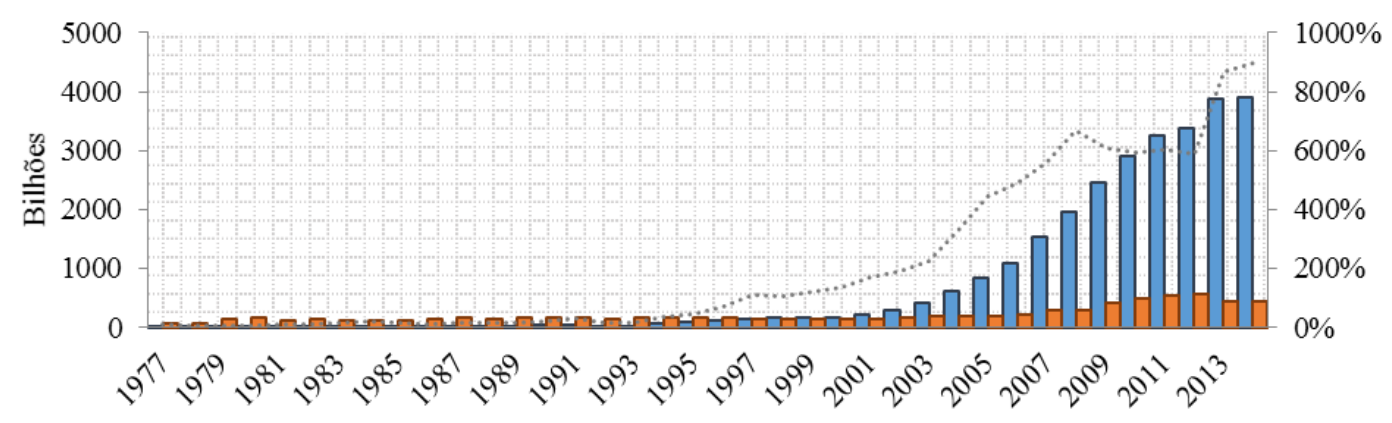

Fonte: Elaboração própria a partir de dados do Banco Mundial.

Considerando o processo até aqui apresentado, faz-se uma ressalva com relação à importância do investimento na China, principalmente do governo. Observa-se que a participação da formação de capital da China, que inclui a formação de capital fixo e a variação de estoque, em relação ao mundo, a Ásia e aos países desenvolvidos tem aumentado continuamente desde 2001, como pode ser visto no Gráfico 6.

\footnotetext{
${ }^{12}$ Ressalta-se que grande percentual das reservas chinesas está aplicada em títulos da dívida norte-americana, ou seja, a China ao aumentar sua capacidade de acumular reserva passou a financiar o quantitative-easing dos EUA.
} 
Gráfico 6: Participação da formação de capital da China em relação ao mundo, países desenvolvidos e Ásia.

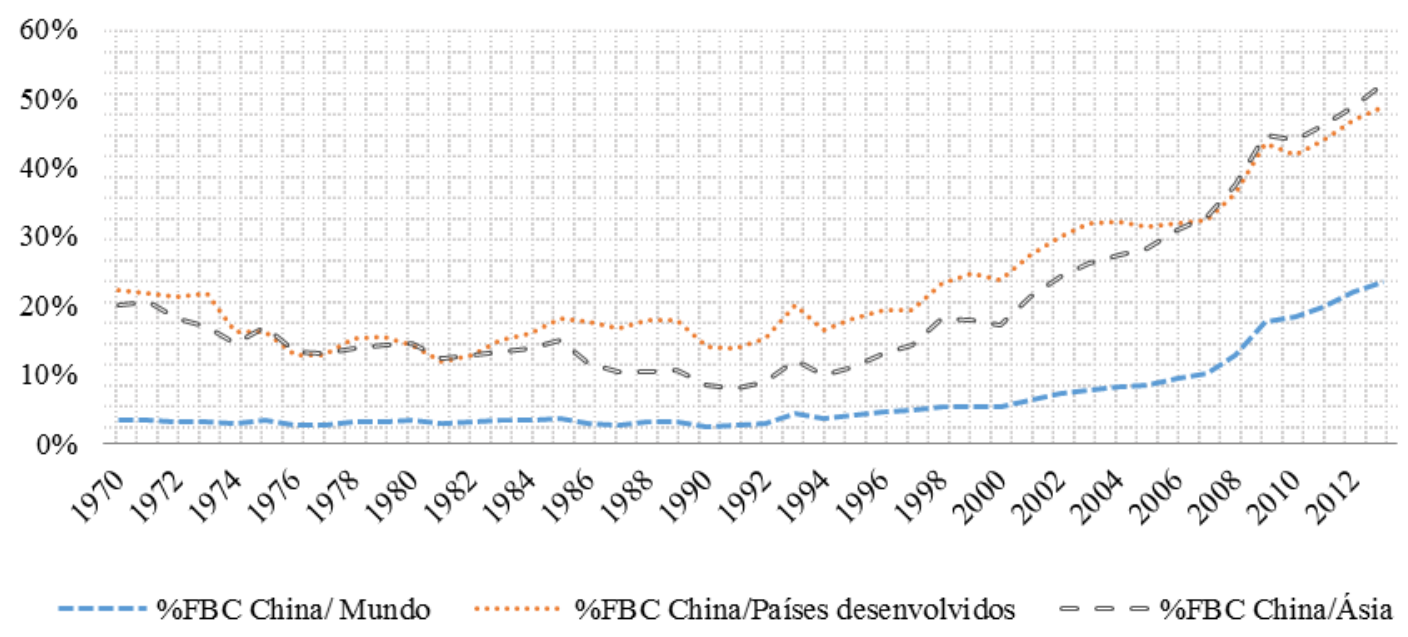

Fonte: Elaboração própria a partir de dados do Banco Mundial.

Com isso, busca-se mostrar a importância do investimento na determinação do crescimento chinês e na consolidação da indústria. Segundo Milaré (2011) é por meio do investimento estatal, por exemplo, que o Estado proporciona planejamento econômico, parte da tríade planejamento-autonomia-controle que, para o autor, proporcionou a consolidação do processo de industrialização de forma relativamente autônoma em relação à ordem internacional. A questão é, portanto, mostrar que a presença do Estado ao viabilizar a formação de capital seja por meio do investimento público ou do direcionamento do investimento externo fez com que, para uma corrente de autores ${ }^{13}$, a variável fundamental do crescimento econômico chinês não fosse o drive exportador, ainda que este tenha papel crucial.

Destaca-se que a condução estatal do processo de desenvolvimento das forças produtivas e, portanto, da economia e sociedade chinesa é um dos fatores que particulariza o movimento do país na lógica dos gansos voadores. Este é um padrão de desenvolvimento e integração regional na Ásia, defendido pelo economista Akamatsu (1962). Nesse modelo, iniciado pelo Japão, quando o país atinge rápido crescimento baseado na exploração de recursos naturais e mão de obra intensiva evolui para produções de produtos mais dinâmicos, ou seja, com maior capacidade de linkages. Nesse movimento, abrem-se oportunidades para a

\footnotetext{
${ }^{13}$ Como Medeiros, Nonnemberg, Nogueira, entre outros.
} 
inclusão de nações vizinhas na divisão internacional do trabalho de forma que essas regiões passam a produzir os produtos que as regiões líderes deixaram de ser competitivas.

Os gansos funcionam com uma lógica "desenvolvimento hierarquizado, mas concatenado entre países com distintos graus de desenvolvimento através de efeitos positivos e realimentadores do comércio e do investimento direto" (MEDEIROS, 1997). O movimento na Ásia se deu do Japão para os Dragões (Hong Kong, Taiwan, Coréia do Sul e Singapura), depois para os Tigres (Malásia, Filipinas, Tailândia, Indonésia) e na sequência para China e o Vietnam. A ideia geral é que existe, portanto, um padrão de desenvolvimento da divisão internacional do trabalho baseada nas vantagens comparativas dinâmicas entre os países da Ásia.

O modelo dos gansos voadores proporcionou um alinhamento das relações chinesas na Ásia permitindo a alavancagem do processo de comercialização da China com os países vizinhos. No entanto, outros aspectos políticos e econômicos também permitiram ao país melhorar seu drive exportador como a classificação de Nação Mais Favorecida pelos EUA estimulando a exportação de produtos têxteis na década de 1980 e a crise asiática de 1997-1998, em que a China conseguiu administrar o impacto desta crise sobre sua economia por meio do estímulo ao investimento público, não alterando sua política cambial de forma prejudicial ao seu desenvolvimento a longo prazo.

O país, por intermédio do aparato estatal pró-industrial, tornou-se peça fundamental na articulação econômica regional após a crise asiática, redesenhando suas relações econômicas com os "gansos voadores" fazendo que, por um lado, a potência expressasse substituição aos produtos asiáticos com relação ao mercado norte-americano e, por outro, representasse um mecanismo complementar, em que o país demandava insumos, parte e componentes de bens de capital, caracterizando o efeito estrutura: importação chinesa de bens intermediários dos países asiáticos; e o efeito escala: demanda produtos intensivos em mão de obra dos países vizinhos (LEÃO, 2011). Esse movimento fez com que Medeiros (2006) elencasse a China como um duplo pólo na economia mundial. A China buscou liderar, dessa forma, o processo de desenvolvimento asiático tornando-se um centro gravitacional na região e diferenciando-se da trajetória tradicional dos gansos.

Nesse movimento, o país acumulou reservas, aumentou o volume de suas exportações e importações, mudou os preços relativos entre produtos básicos e manufaturados por meio de sua elevada demanda por importação de produtos pouco processados (indústrias baseadas em recursos naturais) e exportação de produtos da indústria de transformação, promoveu processo de sinergia comercial com a economia norte-americana tornando-se, portanto, uma economia relevante nas decisões internacionais. A China também conseguiu promover o processo de 
catching up, que pode ser resumidamente analisado pela mudança dos tipos de tecnologias mais exportadas pelo país como apresentado em discussões precedentes.

Além disso, o país iniciou o movimento de internalizar a lógica do desenvolvimento priorizando o consumo e o investimento, diferente da maioria dos outros gansos que se prenderam, predominantemente, a lógica de drive exportador. Dessa forma, conclui-se que a ascensão da China representa mais que um simples movimento nessa lógica. Como ressaltou Oliveira (2008), por intermédio do papel do Estado no processo de desenvolvimento, a China tem superado as barreiras do subdesenvolvimento e migrado de "ganso voador" para "global player". Dessa forma, pode-se afirmar que o país está alcançando o objetivo primordial da sua estratégia nacional de elevar seu status internacional para uma potência capaz de influenciar o sistema internacional.

\section{Centralidade da inovação na estratégia chinesa}

A partir de meados dos anos 2000 a China intensificou o desenvolvimento de setores com maior dinamismo industrial, articulando-se ao cenário internacional por meio da estratégia "going global". Masiero e Coelho (2014) analisam que por intermédio da política industrial focada no processo de inovação em setores chaves, principalmente, químico, eletrônico e metal-mecânico, o país constituiu um tecido industrial internacionalmente competitivo, atraindo empresas internacionais não apenas para produzir no país, mas também para se articular com as empresas nacionais fazendo com que tecnologias próprias fossem produzidas pela China. Esse movimento de inserção internacional tem acirrado a concorrência com players tradicionais, definindo uma "nova geografia econômica".

Mais que isso, percebe-se um modelo articulado pelo Estado capaz de gerar linkages, leverage, learning e indigenous innovation (MASIERO E COELHO, 2014). Ou seja, um modelo estruturado para fazer com que o "made in China" fosse desassociado de baixa qualidade e capacidade de inovação, já que os produtos produzidos na China passaram a contar com aprendizado rápido e articulado aos demais setores e empresas internacionais e também com o desenvolvimento endógeno de inovações, a grande conquista do país.

Nesse sentido, a percepção de produtos "made in China" a "preços chineses", isto é, de baixa qualidade, muito baratos, fabricados por estrangeiros ou por empresas chinesas pouco experientes em manufatura, aos poucos migra para a constatação de produtos desenvolvidos e criados na China, com valores adicionados no país, por meio de inovações em processos e tecnologia, não apenas por multinacionais de fora, mas também por um crescente número de empresas genuinamente chinesas. Com isso, a 
China não se torna apenas o workshop of the world (Gao, 2011), mas um player competitivo em tecnologia, inovação e valor agregado (MASIERO E COELHO, 2014, p. 154).

A lógica produtiva chinesa estaria, nesse processo, conquistando novas vantagens comparativas em que o preço tem deixado de representar uma variável chave de competição. Nesse aspecto, Nonnemberg et al (2008) recapitula os pontos centrais da competitividade do país até os anos 2000 como o fomento de políticas industriais e tecnológicas, políticas macroeconômicas conservadoras, baixo nível de salários, ausência de proteção à propriedade intelectual, câmbio desvalorizado, localização geográfica, dentre outros fatores. Considerando os anos 2005, percebese que o patamar cambial da China, mantido estável até então, começou a ser flexibilizado, permitindo valorizações, incorporaram-se às políticas industriais estratégias de inovação e aumento da renda dos trabalhadores.

De forma geral, parece que a China não depende mais apenas do seu drive exportador, mas também do nível de consumo e investimento interno, ou seja, o modelo de desenvolvimento chinês está se adaptando a um mercado consumidor cada vez maior. Dessa forma, Medeiros (2008) aponta que a elevação dos salários tende a promover "mudanças a favor de um maior crescimento do mercado interno e maior divisão social do trabalho, com uma maior expansão do setor serviços" (MEDEIROS, 2008, p. 7).

Segundo Medeiros (2008), os principais fatores para elevação dos salários foram o processo de valorização do câmbio, que tem elevado o salário em moeda internacional, o aumento do custo de vida e as pressões no mercado de trabalho. Além desses fatores, Li et al (2012) enumeraram outras razões, como:

(1) Reformas institucionais: estabeleceram a criação de incentivos nas empresas estatais, passando a ser permitido pagar salários mais altos e bônus aos trabalhadores mais produtivos. Além disso, houve a formação do mercado externo de trabalho em que o setor privado passou a ter peso na formação desse mercado alcançando cerca de $79 \%$ do emprego total urbano em 2010;

(2) Transição demográfica e escassez de trabalho: houve uma transição demográfica na China, ou seja, um período em que sua força de trabalho passou a aumentar lentamente. Esse aumento gradual coincide com o aumento salarial mais rápido a partir de 1997, já que a taxa de crescimento da força de trabalho da China caiu de 1,9 \% antes de 1997 para 1,4 \% em 1997;

(3) Mudanças estruturais: a migração de trabalhadores rurais para as áreas urbanas nas últimas décadas auxiliou a manter os baixos salários nas áreas urbanas, haja vista que o número de trabalhadores migrantes aumentou de 25 milhões em 1985 para 159 milhões em 2011. No entanto, esse modelo parece estar se esgotando 
já que o crescimento do fluxo de migrantes caiu de 10,8\%, ao ano, antes de 1997, para apenas 4,6\%, em 1997 .

No que diz respeito à divisão social do trabalho na China, percebe-se que esta ainda é difusa e complicada. Morais (2011) descreve que mudanças institucionais no mercado de trabalho chinês nos anos 1990 quebraram a antiga "tigela de ferro onde todos comiam" e o danweil4 que davam ao trabalhador garantias sobre o trabalho e promoviam recomposição da distribuição da força de trabalho no mercado. Entre as consequências, encontram-se o crescimento do emprego informal nas regiões urbanas e o aumento do desemprego formal que tornaram o crescimento dos salários desiguais. Nota-se que os trabalhadores sem registro (waidiren) ocupavam postos não qualificados nas cidades, o que fazia com que fossem uma mão-de-obra substituta imperfeita para o migrante com registro ou residente. Um dos fatores que promoveu o aumento dos "waidiren" foi à flexibilização do hukou ${ }^{15}$ no início dos anos 80.

Dessa forma, Medeiros (2008) elencou como os principais desafios econômicos a serem enfrentados pela China no seu processo de ascensão internacional a mudança da inserção externa, em que se desloca o país de exportador de produtos intensivos em trabalho para produtos com maior valor adicionado, e a mudança no padrão de acumulação em que a elevação do salário deve ser vista como meio para expansão do consumo. Com isso, questiona-se se o modelo de crescimento chinês não estaria sendo orientado pelos investimentos, buscando a substituição de importação de bens intermediários e elevação da capacidade produtiva da indústria pesada, e pelo consumo, pautado da expansão do mercado interno.

Sobre o processo de urbanização chinesa, nota-se que a ascensão da China como fábrica do mundo implicou em transformações aceleradas do processo de urbanização no país, alterando a estrutura do emprego. O deslocamento da população do campo para a cidade garantiu a competitividade da China como exportadora de manufaturas baratas, já que o trabalhador do campo em busca de melhores condições sujeitava-se a baixos salários.

No entanto, de acordo com Gouveia (2012), no fim do século XX, os salários industriais passaram a serem maiores; que permitiu a construção de uma nova etapa do modelo de desenvolvimento chinês em que nascia uma poderosa classe de assalariados que se consolidaria como mais um pilar da estratégia de crescimento. Com isso, pode-se inferir que a ascensão da classe de assalariados não representa

\footnotetext{
14 "Nas cidades, o desmonte do igualitarismo era muito menos palatável, especialmente porque previa a quebra da "tigela de ferro onde todos comiam juntos" e o esfacelamento do danwei, a instituição social urbana que garantia a oferta de emprego vitalício, moradia subsidiada, educação, saúde e previdência a todos " (MORAIS, 2011, p. 100$101)$.

15 Sistema que permite ao governo, entre outras coisas, controlar o fluxo migratório.
} 
um ponto de inflexão ao crescimento chinês, mas sim, uma nova vertente à medida que permitiu, em algum grau, a endogeneização do crescimento.

De acordo com Cintra e Pinto (2015), a China busca por um regime de crescimento sustentável em que, além de um crescimento menos ancorado na exploração depredatória do meio ambiente, vislumbre a realização de um novo contrato social, buscando construir à sua maneira, um Estado de bem-estar que reduza as desigualdades sociais e regionais e a expansão do sistema público de saúde e da previdência social. Como ressalta Cintra e Pinto (2015):

(...) A provisão de bens públicos "universais", o desenvolvimento de uma urbanização e uma industrialização com menor impacto sobre o meio ambiente, a ampliação da renda e do consumo da população são os pilares do planejamento estratégico que visam transformar - ou seja, reformar - o regime de crescimento nos próximos anos (CINTRA E PINTO, 2015, p.8).

Na perspectiva das cadeias globais de valor, avalia-se que a China ainda está inserida como produtora de produtos com menor valor adicionado em relação aos países desenvolvidos, que segundo Cintra e Pinto (2015), ainda estão no topo da hierarquia das cadeias de produção. No entanto, como tem sido o intuito dessa seção, entende-se que há um movimento por parte do Estado chinês em fomentar o desenvolvimento da inovação buscando não apenas agregar valor às exportações, mas também substituir as importações. Esses esforços podem ser avaliados na aprovação do programa de inovação autóctone (indigenous innovation) destacado tanto em Cintra e Pinto (2015) quanto em Cassiolato e Podcameni (2015), de forma que esse ímpeto inovador passou a ser centro do modelo de desenvolvimento chinês.

Esse programa de inovação foi instituído em 2005 e direcionado às especificidades da economia e sociedade locais. O intuito básico era fazer que a China fosse um país com crescimento e desenvolvimento embasados pela inovação em 2020. De acordo com Cassiolato e Podcameni (2015), a estratégia consiste em utilizar o mercado interno para desenvolver novas trajetórias tecnológicas. Essa estratégia ganhou destaque em 2009 com o lançamento do governo de uma circular criando um catálogo de novos produtos nacionais, produzidos pela inovação autóctone, que receberiam tratamento privilegiado nas compras dos governos locais. Os autores ressaltam que a política de inovação priorizou o desenvolvimento de tecnologias voltadas para a construção de um novo paradigma tecnológico que atendesse as especificidades locais, fugindo dos padrões do centro. Por exemplo, o terceiro projeto especial (nova geração de redes de comunicação móvel de banda larga sem fio) tinha como objetivo alcançar, em 2020, 10\% das patentes globais, $25 \%$ do mercado de semicondutores de telecomunicações, $20 \%$ 
do mercado global de hardware de banda larga e 50\% do mercado doméstico de hardware e banda larga (CASSIOLATO E PODCAMENI, 2015).

O plano da China de usar seu mercado interno como fio condutor do seu programa de inovação ganhou força em 2009. O MCT, a Comissão Nacional de Desenvolvimento e Reforma (National Development and Reform Commission NDRC) e o Ministério da Fazenda anunciaram a criação de um catálogo de novos produtos, em âmbito nacional, que receberiam tratamento preferencial nas compras governamentais. Muitas províncias e municípios elaboraram seus catálogos, retirando produtos estrangeiros das compras governamentais locais. Essa iniciativa ainda se concentrou em seis campos de alta tecnologia: i) computadores; ii) produtos de comunicações; iii) equipamentos de escritório modernos; iv) software; v) novas fontes de energia e novos dispositivos de energia; e vi) produtos de alta eficiência energética e poupadores de energia (CASSIOLATO E PODCAMENI, 2015).

Ainda no ano de 2009, o governo avançou mais ainda, com a criação de um catálogo de 240 tipos de equipamentos industriais, em dezoito categorias, para as quais haveria incentivos a fim de que as empresas nacionais produzissem, no intuito de atualizar a base industrial da China. Aquelas que participassem do esforço receberiam uma combinação de incentivos fiscais e subsídios, bem como prioridade nos catálogos de produtos de inovação (CASSIOLATO E PODCAMENI, 2015).

Nessa perspectiva, apresenta-se no Gráfico 7 o percentual de gastos com pesquisa e desenvolvimento em relação ao PIB para China, EUA, Japão, Coreia do Sul, Alemanha, Brasil e México como um indicador proxy da evolução da capacidade de inovar. A perspectiva comparada da análise do indicador visa possibilitar a avaliação da evolução do investimento em P\&D da China em relação a países tradicionalmente inovadores e também em relação a alguns países emergentes. Percebe-se que apesar da razão P\&D/PIB chinês ser menor que dos países líderes e superar apenas as potências em desenvolvimento, representadas pelo Brasil e pelo México, em termos de crescimento da variável no período de 2005 a 2012, a China, com 46,30\%, só não superou a Coreia do Sul que teve crescimento de 53,29\%, mas apresentou maior taxa de crescimento para o indicador em relação a todas as demais regiões, para as quais essa taxa cresceu menos que $20 \%$ no período ${ }^{16}$. Com isso, entende-se que apesar da necessidade do país em articular ainda mais seu modelo de desenvolvimento com ênfase no

\footnotetext{
${ }^{16}$ A China cresceu menos quando se olha para o percentual do P\&D em relação ao PIB. Mas o PIB é maior que o da Coreia. Logo, pode-se inferir que o crescimento absoluto em pesquisa e desenvolvimento seja maior na economia chinesa.
} 
estímulo de atividades inovadoras para superar o gap existente em relação a regiões líderes, este processo já começou.

Gráfico 7: Percentual de P\&D em relação ao PIB para China, EUA, Alemanha, Japão, Coreia do Sul, Brasil e México - 2000 a 2012

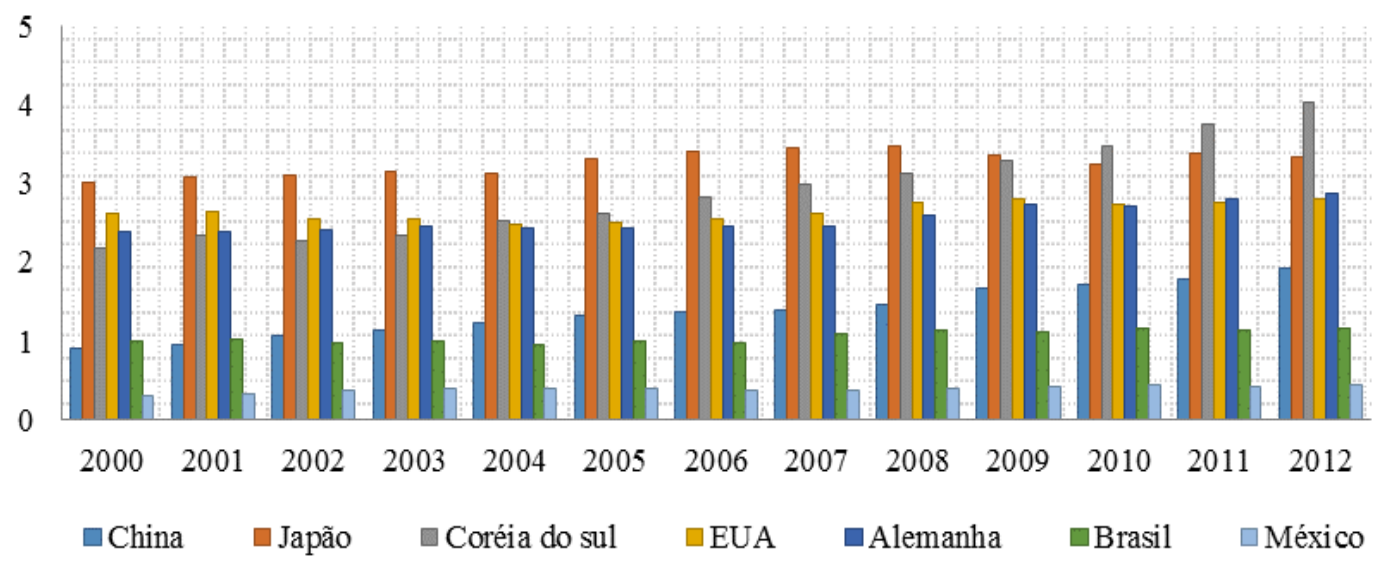

Fonte: Elaboração própria a partir de dados do Banco Mundial.

Para concorrer com os países desenvolvidos a China também buscou pela formação de players no mercado mundial, selecionando empresas e setores a serem incentivados, ou seja, formando os "campeões nacionais". Dentre alguns players chineses de destaque internacional, pode-se citar a Lenovo (computadores), a Huawei (equipamentos de telecomunicações), a Haier (eletrodomésticos e eletroeletrônicos) e a Chery Automobile (automóveis). Inicialmente os players são protegidos das concorrentes internacionais e posteriormente as empresas locais buscam se livrar da necessidade de licenciamentos estrangeiros e desenvolvem uma nova tecnologia e escala produtiva para ganhar concorrência internacional. Destaca-se ainda que nessa busca por uma nova reinserção nas cadeias globais de valor, a China tem se tornado menos dependente da infraestrutura cibernética americana.

Nesse aspecto, buscou-se avaliar a solicitação de patentes pela China comparado a outros países inovadores e a países emergentes junto ao Escritório Europeu $^{17}$ de patentes. Nota-se pelo Gráfico 8 que, embora a China ainda não seja uma grande depositária de patentes, não se sobressaindo em relação a nenhum

\footnotetext{
${ }^{17}$ Para a coleta de dados considerou-se o país avaliado como applicant, o ano analisado e o campo para a busca o Escritório Europeu.
} 
país tradicionalmente inovador, as patentes chinesas apresentaram a maior taxa de crescimento de 2005 a 2015 em relação aos países analisados e, apesar de apresentar inconstância na taxa de crescimento anual, com períodos em que as patentes depositadas cresceram 50\% e outros, como em 2013, caíram 3\%, percebe-se que a maior solicitação de patentes indica que a China tem buscado transformar sua lógica de competição da cópia para a inovação, agregando ainda mais valor ao bem produzido no país.

Além disso, faz-se uma comparação entre a solicitação de patentes chinesas e sul-coreanas. Sabe-se que a Coreia do Sul apresentou uma considerável ascensão econômica e alterou seus padrões de competição internacional agregando valor aos seus produtos, superando barreiras internacionais ao desenvolvimento de potências tardias ${ }^{18}$, exemplo do processo seria a empresa Hyundai. Nesse sentido, observar que a China tem se aproximado da Coreia do Sul na situação de depositária de patentes pode refletir o esforço de uma potência ainda mais tardia na busca pela superação de padrões. Além disso, indica que a China está se aproximando de potências bem-sucedidas na escalada internacional da inovação.

\footnotetext{
${ }^{18}$ Canuto (1994) avalia que a industrialização tardia apresenta descontinuidade nos requisitos tecnológicos, de escala e volume de capital. Para os "tardios" há hiatos em vários segmentos do núcleo básico das atividades de geração e difusão de tecnologia que dificultam a convergência com os países avançados. Além disso, aumentar a densidade da malha industrial requereu a formação de clusters maiores em termos de volume de capital e escala nos ramos de infraestrutura com alta complementariedade técnica e comercial e implicou em maior descontinuidade entre a capacidade instalada e o tamanho dos mercados públicos e privados. Por fim, o autor destaca três ordens de diferenças entre os países tardios e seus antecessores: (i) tecnologia, já desenvolvida e apropriada no exterior; (ii) financiamento, dada maior necessidade de centralização de fundos e exigência de divisas na composição de tais fundos; (iii) presença do Estado, dada a improbabilidade de que os processos locais de acumulação de capital gerassem, por si, a capacidade de enfrentamento as desvantagens concorrenciais e a necessidade de centralização do capital.
} 
Gráfico 8: Patentes depositadas no Escritório Europeu de 2005 a 2015 por México, Brasil, China, Coreia do Sul, Japão, Alemanha, EUA, sendo o país analisado o depositário da patente ${ }^{19}$.

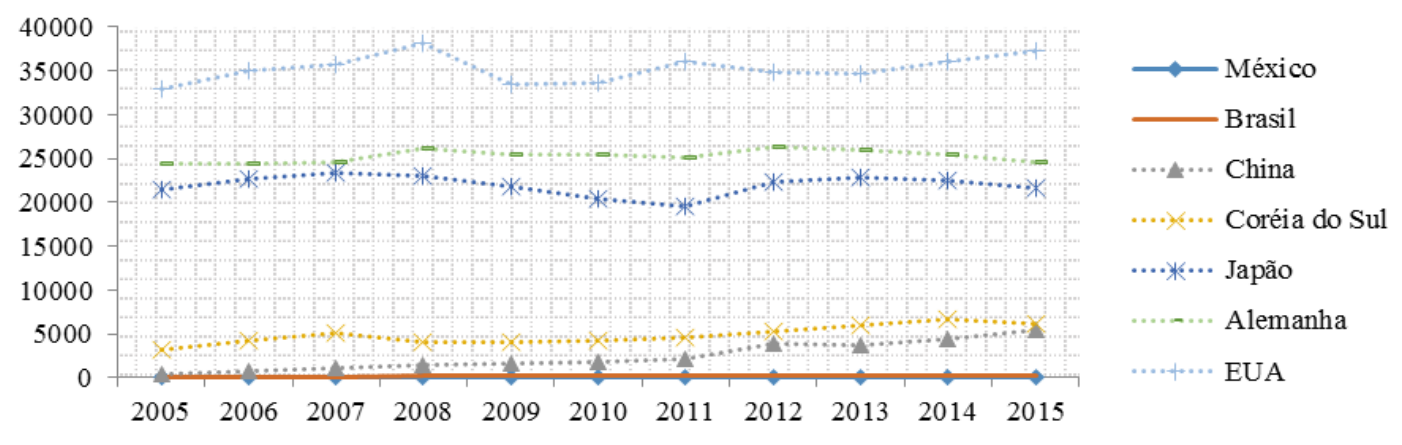

Fonte: Elaboração própria a partir de dados do Espacenet.

Dado o aumento do número de patente solicitadas pela China junto ao Escritório Europeu avaliado no Gráfico 8, analisa-se no Gráfico 9 os domínios tecnológicos aos quais as patentes chinesas pertencem, o que permite analisar em quais domínios houve maior avanço ao longo dos anos de 2005 a 2015. A classificação em subdomínios tecnológicos foi feita por meio dos algoritmos propostos pela World Intellectual Property Organisation (WIPO) seguindo os padrões de classificação tecnológica ISI-OST-INPI, de forma que se obtiveram 30 subdomínios tecnológicos. Para uma análise compacta, agregou-se os 30 subdomínios tecnológicos em 7 domínios tecnológicos proposto pelo Observatoire des Sciences et des Techniques (OST), obtendo, portanto, o número de patentes solicitadas pela China entre 2005 e 2015 nas áreas de Eletrônica-eletricidade, Instrumentação, Química-materiais, Farmácia e Biotecnologia, Procedimentos industriais, Máquinas-mecânicas-transporte, Consumo de famílias e Construção Civil, como pode ser visto no Gráfico 9.

Nota-se pelo Gráfico 9 que a solicitação de patentes chinesas apresenta maior valor absoluto no domínio tecnológico de Eletrônica-eletricidade, estimulado principalmente pelos subdomínios tecnológicos da telecomunicação, da tecnologia da informação e de dispositivos elétricos, da engenharia e energia elétrica, embora o primeiro tenha sido mais relevante durante todo o período analisado. O segundo maior subdomínio tecnológico é o Química-materiais, com

\footnotetext{
${ }^{19}$ As patentes brasileiras e mexicanas aparecem sobrepostas por um problema de escala gráfica. Embora ambos os países sejam pequenos depositários de patentes no escritório europeu, o Brasil tem maior número de patentes que o México. Em média, entre 2005 e 2015, a solicitação de patentes do México representou 30\% das solicitações brasileiras.
} 
maior representatividade do subdomínio Química Orgânica Fina. O terceiro maior domínio tecnológico é o de Instrumentação, sendo o subdomínio mais relevante o de Análise, medição e tecnologia de controle. Além destes, podem-se analisar os quatro demais domínios tecnológicos no Gráfico 9.

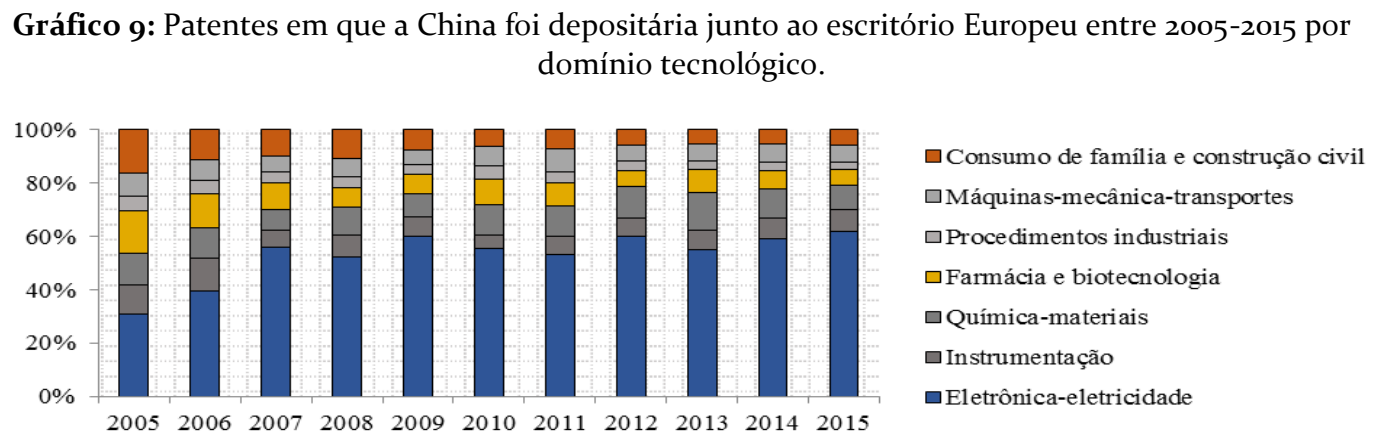

Fonte: Elaboração própria a partir de dados do World Intellectual Property Organisation (WIPO)

Percebe-se pela análise dos domínios tecnológicos que avanços importantes foram conduzidos pela China principalmente considerando o aumento do número de patentes no domínio de Eletrônico-eletricidade e a baixa solicitação de patentes na área de procedimentos industriais, que tem como subdomínio tecnologias de pouca intensidade tecnológica como o processamento de materiais, têxtil e papel e processamento agrícola. Dessa forma, pode-se concluir por intermédio desses indicadores que além do aumento na solicitação de patente, a China tem ampliado ainda mais a solicitação de patentes em áreas relevantes considerando que a nova perspectiva do modelo de desenvolvimento tem como aspecto central a inovação.

Aliado a estratégia de inovação, pós-crise de 2008, a China ampliou a capacidade de alcance dos seus investimentos estrangeiros, ampliando a integração com a economia regional. Cintra e Pinto (2015) classificam o movimento com "um dos fenômenos empresariais mais profundos das últimas décadas". De acordo com os autores, a China se configura como um dos maiores países investidores do mundo, centrando-se na construção de infraestrutura que permita melhor integração regional como estradas, redes de energia, entre outros.

Apesar do intenso processo voltado à inovação engendrado pelo governo chinês, a maior parte das empresas ainda tinha sua produção subordinada às grandes cadeias de valor. Dessa forma, as ligações locais ou nacionais entre as indústrias eram fracas ou lentamente desenvolvidas. $\mathrm{O}$ próprio presidente $\mathrm{Xi}$ Jinping discursou sobre o tema, no qual avaliou: 
A fundação chinesa para a inovação e ciência, tecnologia e inovação ainda não é firme. A capacidade chinesa para a inovação autóctone, especialmente a inovação radical, ainda é fraca. Fundamentalmente, a China ainda é controlada em diversos campos da ciência, em áreas tecnológicas, consideradas chave (EUROPEAN UNION CHAMBER OF COMMERCE IN CHNA, 2017, p. 7, tradução nossa).

Dessa forma, a China lançou um plano chamado China Manufacturing 2025 (CM2025). Este prevê a maior independência à indústria chinesa em áreas de máquinas e equipamentos estratégicos, além de um aumento da qualidade da base industrial. Outra intenção do plano é que a China seja líder global da manufatura até 2049, no 100 a aniversário de fundação da República Popular da China (EUROPEAN UNION CHAMBER OF COMMERCE IN CHINA, 2017).

As áreas consideradas mais importantes para o desenvolvimento chinês são as listadas: próxima geração de tecnologia da informação; robótica; engenharia marítima com tecnologia de ponta; veículos elétricos e poupadores de energia; equipamentos avançados de trens; material elétrico; maquinas e equipamentos para agricultura; novos materiais; biofarmacêuticos. Além disso, o plano ainda prevê algumas metas bem audaciosas: (i) 40\% dos componentes e materiais básicos serão produzidos domesticamente até 2020, aumento para 70\% até 2025; (ii) 30\% de redução de custos operacionais, ciclos de produção e defeitos em produtos, até 2020, aumento para 50\% até 2025; (iii) 15 centros de inovação até 2020 e 40 até 2025 (EUROPEAN UNION CHAMBER OF COMMERCE IN CHINA, 2017).

Outro ponto essencial desse plano é a adoção de medidas que busquem inserir a indústria chinesa no movimento de fomento à indústria $4.0^{20}$. Esta também é a resposta chinesa às iniciativas alemã e francesa, nas quais o Estado não somente planeja, mas incentiva o desenvolvimento de tecnologias voltadas à tecnologia da informação e robótica. Muito embora a China ainda opere na indústria 2.0, argumenta-se que a existência de grandes players chineses em campos do mundo digital, como o Baidu e Alibaba, colabora no avanço à indústria mais intensiva em tecnologia, pois essas empresas apresentam capacidades importantes, no que diz respeito à tecnologia da informação e big data. Além disso, vale ressaltar que o $\mathrm{CM}_{2025}$ inclui subsídios e planos de investimentos às áreas de tecnologia mais avançada. Para as empresas ligadas à robótica e carros elétricos, em particular, os governos locais e central proporcionarão suporte às firmas, desde empréstimos até a cobertura de parte dos custos de tais empresas para a instalação

\footnotetext{
${ }^{20}$ A indústria 4.o se caracteriza pelo incremento substancial da digitalização na manufatura com sistemas que se utilizam de big data, sistemas armazenamento em nuvem e desenvolvimento da tecnologia da informação, que permitem o compartilhamento e análise de dados por toda a cadeia industrial de valor, conectando redes de pessoas e robôs, que passam a interagir e trabalhar juntos.
} 
de seus produtos até o consumidor. Portanto, percebe-se uma robusta movimentação chinesa em direção à inovação própria voltada à China, sem deixar de olhar o avanço que as economias desenvolvidas estão realizando, principalmente, em setores da fronteira tecnológica (EUROPEAN UNION CHAMBER OF COMMERCE IN CHINA, 2017).

Como considerações finais, avalia-se que para além de uma reinserção internacional diferenciada, se a China ao fomentar o mercado interno e garantir por meio da atuação do Estado nas empresas públicas à demanda para produtos produzidos internamente, está incentivando que o modelo de desenvolvimento interno seja puxado pela demanda agregada. Nessa perspectiva, segundo Oreiro, Nakabash e Souza (2009), o primeiro aspecto a ser avaliado é a disponibilidade de capital da economia, pautada pelas decisões de investimento, que por sua vez são ancoradas no crescimento da demanda agregada (desde que atendida à restrição de taxa de retorno maior que o custo do capital).

Outro aspecto é o progresso tecnológico, que por essa teoria, é dado pela acumulação prévia de capital, estimulada pelo ritmo de crescimento da demanda agregada. Com relação ao progresso tecnológico, o modelo ainda destaca a "lei de Kaldor-Verdoon" em que o crescimento da produtividade do trabalho passa, com a criação de economias dinâmicas de escala, a estar relacionado ao crescimento da produção da economia, ou seja, passa a estar relacionado com o ritmo do crescimento da demanda agregada. A China ao fomentar a demanda agregada com grande participação do Estado por meio de gastos e investimentos e, recentemente, com a expansão do mercado interno, busca internalizar ainda mais a raiz do seu dinamismo que apesar de não ser independente do cenário internacional - haja vista a importância das exportações - nunca esteve estritamente ligada ao mercado externo.

Destaca-se ainda que não é interessante que os países e suas empresas absorvam no processo de desenvolvimento apenas o know-how, definido por Canuto (1994) como a capacidade de obter inovações incrementais e adaptativas na fabricação, no investimento e na inovação, mas também construir o know-why. O autor define esse conceito como os princípios científicos e tecnológicos relacionados à produção e à mudança técnica necessárias para a realização de inovações. Parece, portanto, ser o objetivo do país asiático construir o conhecimento necessário para avançar no desenvolvimento de elos mais nobres na sua estrutura produtiva.

\section{Considerações finais}

O presente trabalho apresenta a compreensão do processo históricoeconômico chinês por meio do desenvolvimento e das transformações no processo 
de industrialização do país. Entende-se que o período Deng Xiaoping foi caracterizado por transformações políticas e econômicas, dado o ímpeto revolucionário do líder chinês em permitir o processo de abertura econômica assegurando um direcionamento dos benefícios do processo ao desenvolvimento local. Essa articulação fez com que diversos autores caracterizassem a abertura chinesa como diferenciada, dado que por intermédio desse processo criaram-se as Zonas Econômicas Especiais que estimulavam a produção local de uma parte da cadeia produtiva global, ou seja, a China buscava-se inserir na cadeia global em qualquer etapa na busca por know how. Nessa etapa também foi estimulada a entrada de Investimento Direto Externo buscando fomentar a formação de capital no país além de impulsionar o catching up e atrair técnicas modernas de gestão. Percebe-se que cada passo político, nesse período, era envolvido por um objetivo de formar e consolidar uma potência econômica.

Nesse processo, destaca-se a importância da atuação do Estado chinês, principalmente, sobre os preços macroeconômicos como os juros e o câmbio. Além do controle sobre o sistema bancário que permitia a concessão de créditos a baixas taxas de juros, que estimula os investimentos, e mantendo as taxas de câmbio desvalorizadas, estimulando a produção para exportação. Portanto, considerando o processo de abertura e a condução do Estado para promover a entrada de capital em áreas prioritárias, o país passou a ser atrativo ao investimento externo, que garantia além do aprendizado, altos níveis de exportação e, com isso, a formação de reservas.

Buscando fortalecer laços internacionais para aumentar o mercado consumidor para seus produtos, em 2001, a China passou a fazer parte da Organização Mundial do Comércio, elevando sua participação na corrente de comércio internacional. Essa nova realidade comercial trouxe a China o rótulo de "fábrica do mundo". No entanto, essa caracterização referia-se a alta comercialização chinesa de produtos de baixo valor agregado e, com o adensamento do tecido industrial e o redirecionamento da estratégia produtiva chinesa para a inovação, esta passou a ser um entrave para a nova lógica. Nessa perspectiva, em 2005 foi instituído um programa para a inovação que busca fazer com que o crescimento e o desenvolvimento da economia chinesa estejam embasados na inovação, ou seja, o país busca construir o know-why. A estratégia consiste em utilizar o mercado interno para desenvolver novas trajetórias tecnológicas, superando a necessidade de estar ancorado ao centro do desenvolvimento para ter acesso à inovação, trata-se da busca por endogeneizar o núcleo de progresso técnico.

Como alicerce às novas perspectivas de desenvolvimento tecnológico e industrial, a China tem como objetivo estimular o processo de internalização do modelo de desenvolvimento, fomentando uma nova vertente da demanda 
agregada - o consumo das famílias - e o desenvolvimento da inovação como atividade core do modelo. As transformações estruturais da economia resultaram em mudanças sociais por intermédio, entre outros fatores, do aumento dos salários o que, por sua vez, permitiu a ampliação da classe consumidora. Dessa forma, por meio de elevados gastos estatais, altos níveis de investimento, que agregam valor e buscam na inovação o caminho do progresso, e o fomento da classe consumidora, o país tem ampliado a capacidade da demanda agregada em ser a alavanca de seu modelo de desenvolvimento.

Referências

ACIOLY, L. China: uma inserção diferenciada. Rev. Economia política internacional: uma análise estratégica [S.l.], n. 7, out./dez. 2005. Disponível em: $<$ http://goo.gl/j3zMdr>. Acesso em 15 jun. 2017.

AKAMATSU K. A historical pattern of economic growth in developing countries. Journal of Developing Economies, 1(1):3-25, March-August, 1962. DOI: https://doi.org/10.1111/j.1746-1049.1962.tbo1020.X

AMSDEN, A. H. A ascensão do "resto": Os desafios ao ocidente de economias com industrialização tardia. Tradução: Roger Maioli dos Santos. Editora da Unesp. São Paulo, p. 227-285, 2004.

CANO, W. "A desindustrialização no Brasil". Textos para discussão, Campinas: Instituto de Economia, Unicamp, no 200, p. 26, janeiro de 2012. Disponível em: <www.eco.unicamp.br/docprod/downarq.php?id=3235\&tp=a>. Acesso em 15 jun. 2017.

CANUTO, O. Os (des)caminhos da industrialização tardia. Ed. Nobel, 1994.

CASSIOLATO, J.E; PODCAMENI, M.G.V.B. As políticas de ciência, tecnologia e inovação na China. In: CINTRA, M.A.M; BENEDITO, E.S.F; PINTO, E.C. (Org.). China em transformação: dimensões econômicas e geopolíticas do desenvolvimento. Rio de Janeiro: IPEA, 2015. Capítulo 1o. Disponível em: < http://goo.gl/7gf4Tu>. Acesso em 27 jul. 2017.

CELINO, D. A. B. As zonas de desenvolvimento econômico como instrumento de políticas públicas: a estratégia de desenvolvimento econômico da China. 2006. $133 \mathrm{f}$. Dissertação (Mestrado em administração) - Universidade de Brasília, Brasília, 2006. Disponível em:< http://repositorio.unb.br/bitstream/10482/2185/1/2006_Eduardo\%20Andr\%C3\%A9\%2ode\% 2oBrito\%2oCelino.pdf>. Acesso em o5 jun. 2017. 
CHANG, H. J. "Kicking Away the Ladder". Post-autistic economics review, n. 15 (3), pp. 15. Set/2002. Disponível em:<http://www.paecon.net/PAEReview/issue15/Chang15.htm>. Acesso em 28 fev. 2018.

CINTRA, M. A. M; PINTO, E. A. China em transformação: transição e estratégias de desenvolvimento. Revista de Economia Política, v. 37, n. 2 (147), pp. 381-40o, abriljunho/2017. Disponível em: < http://goo.gl/m82hLx>. Acesso em 16 ago. 2017.

CUNHA, S.F; XAVIER, C.L. Fluxos de investimento direto externo, competitividade e conteúdo tecnológico do comércio exterior da China no início do século XXI. Revista de Economia Política. v. 30, n. 3, p. 491-510. jul-set/2010. Disponível em: <http://goo.gl/RWzwGQ>. Acesso em 16 jun. 2017.

DOSI, G. Sources, procedures and microeconomic effects of innovation. Journal of Economic Literature, 26(3), p.1120-1171, set/1988. Disponível em:<http://dimetic.dimeeu.org/dimetic_files/DosiJEL1988.pdf >. Acesso em 20 jun. 2017.

EUROPEAN UNION CHAMBER OF COMMERCE IN CHINA. China Manufacturing 2o25: Putting industrial policy ahead of market forces. China, 2017.

ESPACENET [internet]. European Patente Office. Disponível em:< http://worldwide.espacenet.com/advancedSearch?locale=en_EP>. Acesso em 20 jun. 2016.

GOUVEIA, E.M. Salários industriais, acumulação de capital e exportações na China. 2012. 190 f. Dissertação (Mestrado em economia) - Universidade Federal do Rio de Janeiro, Rio de Janeiro, 2012. Disponível em: <http://goo.gl/16srTl>. Acesso em o5 ago. 2016.

LEÃO, R.P.F. O padrão de acumulação e o desenvolvimento econômico da China nas últimas três décadas: uma interpretação. 2010. 192 f. Dissertação (Mestrado em Economia) - Universidade Estadual de Campinas, Campinas, 2010.

LI, H. et al. The End of Cheap Chinese Labor. Journal of Economic Perspectives, vol. 26, no 4, pp. 57-74, 2012. Disponível em: <http://goo.gl/2OHxvw>. Acesso em o2 dez. 2016.

LUNDVALL, B. National Innovation Systems - Analytical Concept and Development Tool. Industry and Innovation. V.14. $\mathrm{n}$ 1. P.95-119, fevereiro/2007. Disponível em:<https://myweb.rollins.edu/tlairson/pek/nis.pdf>. Acesso em 20 de jun. 2017.

MASIERO, G.; COELHO, D. B. A política industrial chinesa como determinante de sua estratégia going global. Revista de Economia Política, vol. 34, no 1 (134), pp. 139-157, Jan./Mar. 2014.

Disponível 
em:<http://www.scielo.br/scielo.php?script=sci_arttext\&pid=So101-31572014000100009>. Acesso em 20 nov. 2016.

MAZZUCATO, M. The entrepreneurial state. Londres: Demos, 2011. P. 29-46.

MAZZUCATO, M. Building the entrepreneurial state: A new framework for envisioning and evaluating a mission-oriented public sector, Levy Economics Institute, No. 824, p. 1-24, jan./2015.

Disponível

em: <https://www.econstor.eu/bitstream/10419/109993/1/815376626.pdf>. Acesso em 26 fev. 2018.

MEDEIROS, C. A. A China como um Duplo Pólo na Economia Mundial e a Recentralização da Economia Asiática. Revista de Economia Política, v. 26, n. 3 (103), pp. 381-40o. JulhoSetembro/20o6.

MEDEIROS, C. A. Desenvolvimento Econômico e Ascensão Internacional. In: Conferência Nacional de Política Externa e Política Internacional, 3, p. 19, Brasília. Fundação Alexandre Gusmão, 2008.

MEDEIROS, C. A. Globalização e inserção internacional diferenciada da Ásia e América Latina. In: TAVARES, M. C., FIORI, J. L (Org.). Poder e dinheiro. Uma economia política da globalização. Rio de Janeiro: Vozes, 1997.

MILARÉ, L.F.L. O processo de industrialização chinesa: uma visão sistêmica. 2011. 176 f. Dissertação (Mestrado em Economia) - Universidade Federal de São Carlos, Sorocaba, 2011.

MORAIS, I. N. Desenvolvimento econômico, distribuição de renda e pobreza na China contemporânea. 2011. 209 f. Tese (Doutorado em economia) - Universidade Federal do Rio de Janeiro, Rio de Janeiro, 2011.

MORCEIRO, P. C. Desindustrialização na economia brasileira no período 200o-2o11: abordagens e indicadores. 2012. 206f. Dissertação (Mestrado em Economia) Universidade Estadual Paulista “Júlio De Mesquita Filho” (UNESP), Araraquara, 2012.

NONNEMBERG, M. J. B. Participação em cadeias globais de valor e desenvolvimento econômico. Boletim de Economia e Política Internacional, n. 17, maio/ago. 2014, p. 2437, 2014.

NONNENBERG, M.; LEVY, P.; NEGRI, F.; COSTA, K. O Crescimento Econômico e a competitividade chinesa. Instituto de Pesquisa Econômica Aplicada, texto para discussão, abril, p. 28, 2008. 
OLIVEIRA, G. C. O estado e a inserção ativa na economia: a estratégia de desenvolvimento econômico da China. Revista de Economia, v. 34, n. 3 (ano 32), p. 61-88, set./dez. 2008. Disponível em:<http://www.scielo.br/scielo.php?script=sci_nlinks\&ref=ooo194\&pid=So1013157201400020000400048\&lng=pt >. Acesso em 20 jun. 2016.

OREIRO, J.L; NAKABASHI, L; SOUZA, G. A Economia Brasileira Puxada pela Demanda Agregada. Revista de Economia Política, Vol. 30, N.4. p. 581-603, 2010. Disponível em:< http://www.scielo.br/pdf/rep/v3on4/v3on4ao3.pdf >. Acesso em 20 jul. 2016.

PREBISCH, R. O desenvolvimento da América Latina e seus principais problemas. In: Cinquenta anos de pensamento na Cepal. Boletín económico de América Latina, vol. VII, n" 1, Santiago do Chile, 1962. Publicação da Organização das Nações Unidas, $n^{\circ}$ de venda: 62.II.G.I.

Disponível em:<https://repositorio.cepal.org/bitstream/handle/11362/1611/o03_pt.pdf?sequence=1 $>$. Acesso em 28 jun. 2016.

RELATÓRIO AO $7^{\circ}$ CONGRESSO NACIONAL DO PARTIDO COMUNISTA DA CHINA. Tradução de Jorge Vasconcelos. 15 de outubro 2007. Disponível em:< http://www.odiario.info/b2-img/pcchines.pdf>. Acesso em 20 jun. 2016.

RUIZ, R. M. Polarizações e desigualdades: Desenvolvimento regional na China (1949200o). Texto para discussão n. 299, p.33. Cedeplar-UFMG, Minas Gerais, 2006. Disponível em:< http://www.cedeplar.ufmg.br/pesquisas/td/TD\%20299.pdf >. Acesso em 20 ago. 2016.

SANTANA, C. S. Notas sobre a história da revolução cultural chinesa (1966-1976). História Social, n.17, segundo semestre de 2009. Disponível em:<https://www.ifch.unicamp.br/ojs/index.php/rhs/article/viewFile/279/252>. Acesso em 20 abr. 2016.

SCHMOCH, U. Concept of a Technology Classification for Country. Final Report to the World Intellectual Property Organisation (WIPO), 2008. Disponível em:<http://www.wipo.int/edocs/mdocs/classifications/en/ipc_ce_41/ipc_ce_41_5annex1.pdf>. Acesos em 15 jun 2016.

SCHUMPETER, J. A Teoria do Desenvolvimento Econômico. São Paulo: Abril Cultural. Capítulos 1 e 2, 1985 [1912].

SULEIMAN, Amanda Battaglini. O salto econômico da China: crescimento e mudança. 2008. 45 f. Monografia (Ciências Econômicas) - Faculdade de Economia da Fundação Armando Alvares Penteado, São Paulo, 2008. 
TAMAMES, R. El siglo de China: de Mao a primeira potência mundial. Planeta: Barcelona, 2007.

The Historical National Accounts of the Peoples's Republic of China 1952-1995 [internet]. Dados do PIB de 1952 a 1978. [acesso em 28 mar. 2015]. 2015. Disponível em:<http://www.ier.hit-u.ac.jp/COE/Japanese/online_data/china/china.htm>.

TRADEMAP [internet]. Trade statistics for international business development [acesso em o1 set. 2015]. 2014. Disponível em: < http://www.trademap.org/Index.aspx>.

UNITED NATIONS CONFERENCE ON TRADE AND DEVELOPMENT [internet]. Handbook of statistics. Vários dados [acesso em: o1 set. 2015]. Disponível em: $<$ http://unctadstat.unctad.org/wds/ReportFolders/reportFolders.aspx?sCS_ChosenLang=en $>$.

WORLD BANK. Development Data. Vários dados [acesso em o1 set. 2015]. Disponível em: $<$ http://databank.worldbank.org/data/views/reports/tableview.aspx>.

Recebido em 22.08.17

Aprovado em 06.04.18 